Supporting Information

\title{
Spectroscopic Evidence of Efficient Generation of Dicopper Intermediate in Selective Catalytic Reduction of NO over Cu-Ion- Exchanged Zeolites
}

Akira Oda, ${ }^{*}$ a, b Hitomi Shionoya, ${ }^{\text {a }}$ Yuusuke Hotta, ${ }^{\mathrm{c}}$ Takahiko Takewaki, ${ }^{\mathrm{c}}$ Kyoichi Sawabe, ${ }^{\mathrm{a}}$ Atsushi Satsuma*, a, b

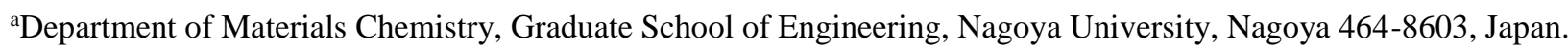

${ }^{b}$ Elements Strategy Initiative for Catalysts and Batteries (ESICB), Kyoto University, Kyoto 615-8520, Japan.

'Science \& Innovation Center, Inorganic Materials Laboratory, Mitsubishi Chemical Corporation, Yokohama 227-8502, Japan.

Corresponding Author

*Email: akira@chembio.nagoya-u.ac.jp (A. O.)

*Email: satsuma@chembio.nagoya-u.ac.jp. (A. S.) 


\section{Table of Contents}

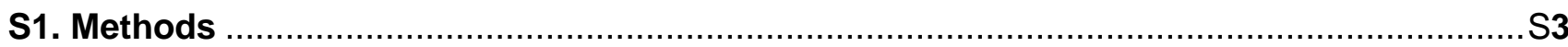

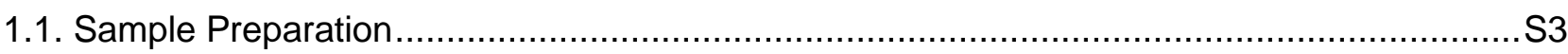

1.2. In Situ UV-Vis-NIR Diffuse Reflectance Spectroscopy..................................................... 3

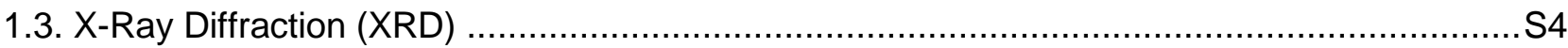

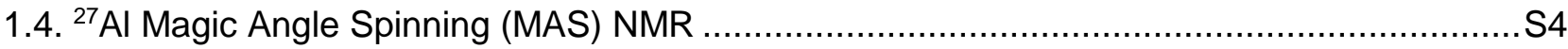

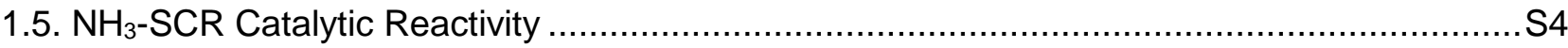

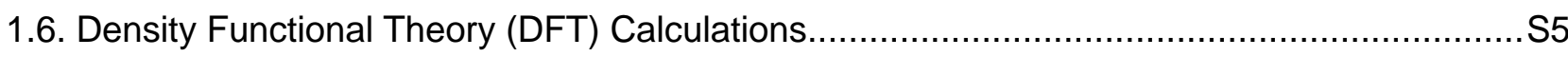

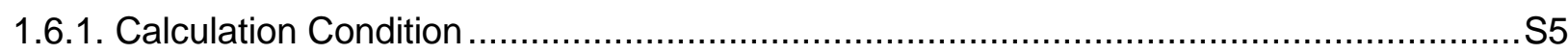

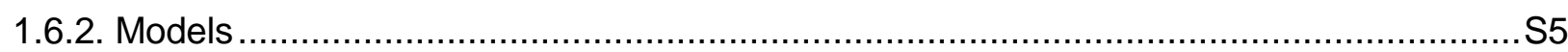

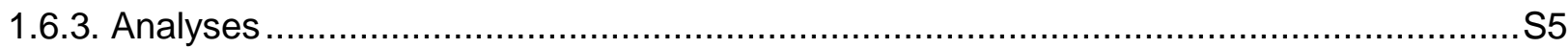

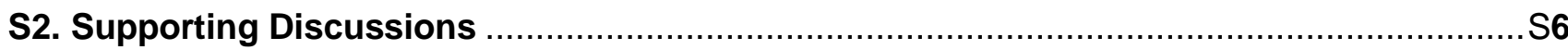

2.1. On the Crystallographic Structures of the Zeolite Catalysts ................................................. 6

2.2. On the Evidence for the Framework Al Atoms for the AI Rich AEI Zeolite ...........................S6

2.3. On the States of the Ion-Exchanged $\mathrm{Cu}^{\prime \prime}$ Species within the Precalcined Samples ..............S6

2.4. On the Validity of Our Spectroscopic Studies on the $\mathrm{Cu}$ Dynamics under the $\mathrm{NH}_{3}$-SCR .....S7

2.5. On the Validity of the DFT Cluster Calculations Using B3LYP-D3 Functional ....................S7

2.6. On the Cluster Size Effect on the DFT Cluster Model of $\left(\mu-\eta^{2}: \eta^{2}\right.$-peroxo)dicopper(II) ..........S8

2.7. On the Spectroscopic Assignment of the UV-Band at $370-350 \mathrm{~nm}$...................................

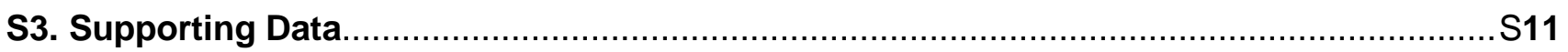

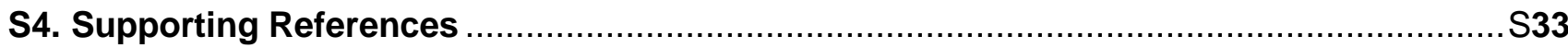




\section{S.1. METHODS}

\section{S.1.1. Sample Preparation}

$1 \mathrm{~g}$ of proton-ion-exchanged AEI zeolite with $\mathrm{Si} / \mathrm{Al}=5.5$ (Mitsubishi Chemical Co., Ltd.) was dispersed in $10 \mathrm{~g}$ of $1 \mathrm{wt} \% \mathrm{Cu}\left(\mathrm{CH}_{3} \mathrm{COO}\right)_{2}$ (Kishida Chemical Co., Ltd.) containing an aqueous solution at $323 \mathrm{~K}$ for $2 \mathrm{~h}$. Next, the sample was rinsed with $100 \mathrm{ml}$ distilled water. The well-rinsed sample was dried overnight at $353 \mathrm{~K}$. From this procedure, a sample of $\mathrm{Cu}$ ion-exchanged AEI zeolite with a $\mathrm{Cu}$ loading of $3.4 \mathrm{wt} \%$ was obtained. By modifying the amount of the $\mathrm{Cu}$ precursor solution, samples with a $\mathrm{Cu}$ loading of $2.0 \mathrm{wt} \%, 2.5 \mathrm{wt} \%$, and $3.1 \mathrm{wt} \%$ were also prepared. By applying the same procedure, $\mathrm{Cu}$ ion-exchanges were also carried out for the AEI zeolite with a Si/Al ratio of 10 (Mitsubishi Chemical Co., Ltd.) and a CHA zeolite with a Si/Al ratio of 12 (also Mitsubishi Chemical Co., Ltd.), through which samples of $\mathrm{Cu} / \mathrm{AEI}(\mathrm{Si} / \mathrm{Al}=10, \mathrm{Cu}$ loading $=3.4 \mathrm{wt} \%)$ and $\mathrm{Cu} / \mathrm{CHA}(\mathrm{Si} / \mathrm{Al}=12, \mathrm{Cu}$ loading $=3.2 \mathrm{wt} \%)$ were obtained. The samples thus prepared were calcined at $823 \mathrm{~K}$ under dry air.

\section{S.1.2. In Situ UV-Vis-NIR Diffuse Reflectance Spectroscopy}

$10 \mathrm{mg}$ of the sample was placed in an in-situ reflectance cell with a quartz window (JASCO Co., Ltd.). UV-Vis-NIR diffuse reflectance spectra were recorded using a JASCO V-770ICO spectrophotometer (JASCO Co., Ltd.) equipped with an integrating sphere attachment and fiber optics. The measurements were carried out in situ conditions (resolution, $0.5 \mathrm{~nm}$; scan rate, $1000 \mathrm{~nm} \mathrm{~min}^{-1}$; temperature, 473-323 K). $\mathrm{BaSO}_{4}$ was used as the reference material. The baseline was recorded under Ar flow $\left(50 \mathrm{ml} \mathrm{min}^{-1}\right)$ at the temperature corresponding to the measurement temperature for the samples.

All samples were precalcined with $10 \% \mathrm{O}_{2}$ (Ar balance) at $773 \mathrm{~K}$. Subsequently, the sample was cooled to $473 \mathrm{~K}$ under $10 \% \mathrm{O}_{2}$ (Ar balance), and the $\mathrm{O}_{2}$ supply was turned off for several minutes. After these pretreatments, the sample was exposed to the gas mixtures of interest. The gas flow rates were controlled by mass flow controllers (Koflok Co., Ltd.). The total flow rate was set to $50 \mathrm{ml} \mathrm{min}^{-1}$ in all experiments.

Intensities of the $d-d$ transition band attributed to the $\mathrm{Cu}^{\mathrm{II}}$ ammine complexes were monitored under 300

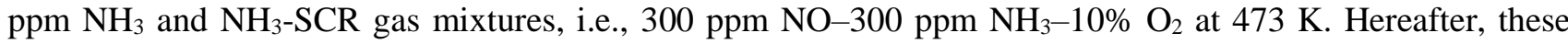
intensities are denoted as $\boldsymbol{I}\left(\mathbf{N H}_{3}\right)$ and $\boldsymbol{I}(\mathbf{S C R})$. The $\boldsymbol{I}\left(\mathbf{N H}_{3}\right)$ was used to quantify the total amount of $\mathrm{Cu}^{\mathrm{II}}$ ammine 
complex present within the sample. The $\mathbf{I}(\mathbf{S C R})$ was used to quantify the amount of the $\mathrm{Cu}^{\mathrm{II}}$ ammine complex generated under the steady-state $\mathrm{NH}_{3}-\mathrm{SCR}$. The steady-state fraction of the $\mathrm{Cu}^{\mathrm{II}}$ ammine complex was defined as $\mathbf{I}\left(\mathbf{N H}_{3}\right) / \mathbf{I}(\mathbf{S C R})$. The validity of our quantitative analyses was confirmed in the calibration curve, i.e., linear relationship between $\boldsymbol{I}\left(\mathbf{N H}_{\mathbf{3}}\right)$ and $\mathrm{Cu}$ loadings.

On the basis of the literature, ${ }^{1}$ the transient experiment regarding the $\mathrm{Cu}^{\mathrm{I}} \rightarrow \mathrm{Cu}^{\mathrm{II}}$ reoxidation process was performed. The sample was prereduced with $300 \mathrm{ppm} \mathrm{NO}-300$ ppm NH 3 at $473 \mathrm{~K}$, and subsequently exposed to 300 ppm NO-300 ppm NH $\mathrm{NH}_{3}-10 \% \mathrm{O}_{2}$. The transient $\mathrm{Cu}^{\mathrm{II}}$ species during the $\mathrm{Cu}^{\mathrm{I}} \rightarrow \mathrm{Cu}^{\mathrm{II}}$ reoxidation process was traced by monitoring the intensity of the $d-d$ transition band at $710 \mathrm{~nm}$ with an interval of 0.5 seconds.

\section{S.1.3. X-Ray Diffraction (XRD)}

XRD patterns of the samples were collected on a diffractometer (Rigaku Mini Flex II) with a Cu K $\alpha$ X-ray source $(30 \mathrm{kV}, 15 \mathrm{~mA})$.

\section{S.1.4. ${ }^{27}$ Al Magic Angle Spinning (MAS) NMR}

${ }^{27} \mathrm{Al}$ MAS NMR was recorded on a JNM-ESCA $700 \mathrm{MHz}$ NMR spectrometer (JEOL) operating at a magnetic field of $16.4 \mathrm{~T}$ and a ${ }^{27} \mathrm{Al}$ Larmor frequency of $182.43 \mathrm{MHz}$. A $3.2 \mathrm{~mm}$ diameter zirconia rotor was used at a rotation speed of $\sim 15 \mathrm{kHz}$. The ${ }^{27} \mathrm{Al}$ MAS NMR spectrum was acquired using $0.6 \mu$ s pulses, a $2 \mathrm{~s}$ recycle delay, and 512 scans. The $\mathrm{AlK}\left(\mathrm{SO}_{4}\right)_{2} \bullet 12 \mathrm{H}_{2} \mathrm{O}$ was used as a chemical shift reference.

\section{S.1.5. $\mathrm{NH}_{3}-\mathrm{SCR}$ Catalytic Reactivity}

$\mathrm{NH}_{3}$-SCR reactions were carried out in a fixed-bed flow reactor under atmospheric pressure. A $0.5 \mathrm{~g}(1.0$ $\mathrm{mL})$ of the powdered $\mathrm{Cu} / \mathrm{AEI}(5.5,3.4)$ sample was pressed, crushed, and sieved $(0.6-1.0 \mathrm{~mm})$ prior to use. The feed gas contains $350 \mathrm{ppm} \mathrm{NO}-385 \mathrm{ppm} \mathrm{NH}_{3}-15 \% \mathrm{O}_{2}-5 \% \mathrm{H}_{2} \mathrm{O}$. The space velocity (SV) was $200000 \mathrm{~h}^{-1}$. The reaction temperature was varied from $433 \mathrm{~K}$ to $773 \mathrm{~K}$ in steps of ca. $50 \mathrm{~K}$. Concentrations of the NO gas were measured by the $\mathrm{NO}_{\mathrm{x}}$ analyzer (YANACO, ECL-88OX). The NO conversion was defined as

$$
N O \text { conversion }(\%)=\frac{N O_{\text {in }}-N O_{\text {out }}}{N O_{\text {in }}} \times 100
$$

Where $\mathrm{NO}_{\text {in }}$ means the concentration of the inlet $\mathrm{NO}$ gas, whereas $\mathrm{NO}_{\text {out }}$ means the concentration of the outlet NO gas. 


\section{S.1.6. Density Functional Theory (DFT) Calculations}

S.1.6.1. Calculation Condition. All DFT cluster calculations were performed using a Gaussian 16 program. A B3LYP functional was used, with 6-311+G(d,p) basis set for $\left[\mathrm{Cu}_{2} \mathrm{O}_{x}\left(\mathrm{NH}_{3}\right)_{4}\right]^{2+}$ core $(x=1$ or 2$)$ and 6-31G(d) basis set for remaining atoms. The self-consistent field (SCF) convergence criterion of $10^{-8}$ au was applied to all calculations.

S.1.6.2. Models. We constructed a DFT cluster model, i.e., $\left[\mathrm{Cu}_{2} \mathrm{O}_{2}\left(\mathrm{NH}_{3}\right)_{4}\right]-\mathrm{Al}_{2} \mathrm{Si}_{34} \mathrm{O}_{54} \mathrm{H}_{36}$ geometry, by the following procedure. First, an AEI cage having 36T sites was truncated from the crystallographic structure of the AEI zeolite. The peripheral parts were capped by $\mathrm{H}$ atoms for charge compensation. Next, two Si atoms in the lattice were replaced with two $\mathrm{Al}$ atoms to reproduce the ion-exchangeable site. $\mathrm{A}\left[\mathrm{Cu}_{2} \mathrm{O}_{2}\left(\mathrm{NH}_{3}\right)_{4}\right]^{2+}$ cation was positioned in the vicinity of the framework $\mathrm{Al}$ sites to meet the charge compensation requirement from two framework Al sites. Finally, the coordinates of all atoms except the terminated $\mathrm{H}$ atoms were fully optimized.

Both the antiferromagnetic and ferromagnetic $\mathrm{Cu}_{2} \mathrm{O}_{2}$ electronic structures were considered for calculations on the model of $\left(\mu-\eta^{2}: \eta^{2}\right.$-peroxo)dicopper(II). For calculations on the antiferromagnetic form, $\alpha$ and $\beta$ spin densities were designated using guess=fragment (keyword and option in Gaussian software). In all calculations, the electronic-ground state was determined as the antiferromagnetic dicopper form; the antiferromagnetic form was stable than the ferromagnetic form by $4.9 \mathrm{~kJ} \mathrm{~mol}^{-1}$. Thus, in the manuscript, we focused only on the computational results of the antiferromagnetic $\left(\mu-\eta^{2}: \eta^{2}\right.$-peroxo)dicopper(II) form.

We also constructed other candidates, i.e., $S=0$ bis( $\mu$-oxo)dicopper(III), $S=1$ ( $\mu-\eta^{1}: \eta^{1}$-peroxo)dicopper(II), $S=1\left(\mu\right.$-oxo)dicopper(II), encapsulated within the AEI cage, by the procedures similar to the $\left(\mu-\eta^{2}: \eta^{2}-\right.$ peroxo)dicopper(II).

S.1.6.3. Analyses. Vibrational frequency calculations were performed on the optimized geometries of $(\mu-$ $\eta^{2}: \eta^{2}$-peroxo)dicopper(II), and no imaginary frequency was confirmed; thus, the optimization was considered to be correct. To simulate the UV-Vis-NIR spectra of the copper-oxygen species encapsulated within the AEI cage, time-dependent (TD) DFT calculations were performed on the optimized geometries using a TD keyword. All calculations were performed at B3LYP/6-311+G(d,p), 6-31G(d) level. 


\section{S.2. Supporting Discussions}

\section{S.2.1. On the Crystallographic Structures of the Zeolite Catalysts}

The crystallographic structures of the $\mathrm{Cu} / \mathrm{AEI}(5.5,3.4), \mathrm{Cu} / \mathrm{AEI}(10,3.4)$, and $\mathrm{Cu} / \mathrm{CHA}(12,3.2)$ samples were analyzed by XRD measurements. The crystallographic structures of the AEI and CHA zeolites were confirmed by their XRD profiles (Figure S1).

\section{S.2.2. On the Evidence for the Framework Al Atoms for the Al Rich AEI Zeolite}

Through the ${ }^{27} \mathrm{Al}$ MAS NMR measurement on the $\mathrm{Cu} / \mathrm{AEI}(5.5,3.4)$ sample with a rich $\mathrm{Al}$ content, it was confirmed that the almost all $\mathrm{Al}$ atoms are incorporated into the $\mathrm{AEI}$ zeolite framework, despite the detection of the small fraction of the extra framework $\mathrm{Al}$ atom (Figure S2).

\section{S.2.3. On the States of the Ion-Exchanged Cu" Species within the Precalcined Samples}

The states of the ion-exchanged copper species were characterized by in-situ UV-Vis-NIR spectroscopy. First, the samples were calcined at $773 \mathrm{~K}$ under the $10 \% \mathrm{O}_{2}$ gas flow. After that, the samples were cooled to $473 \mathrm{~K}$ under the $10 \% \mathrm{O}_{2}$ gas flow. The $\mathrm{O}_{2}$-supply was turned off, and the UV-Vis-NIR spectra were recorded (Figure S3). For the Cu/AEI $(5.5,3.4)$ sample having a relatively low Si/Al ratio, the $d$ - $d$ transition band of divalent copper was observed at around $850 \mathrm{~nm}$. This band is assignable to the single $\mathrm{Cu}^{\mathrm{II}}$ ion anchored on the 6MR site containing two framework $\mathrm{Al}$ atoms. ${ }^{2}$ On the other hand, for the $\mathrm{Cu} / \mathrm{AEI}(10,3.4)$ and $\mathrm{Cu} / \mathrm{CHA}(12$, 3.2) samples having relatively high $\mathrm{Si} / \mathrm{Al}$ ratios, the multiple $d-d$ transition bands of divalent copper were observed in the $1200-400 \mathrm{~nm}$ region. These bands are assignable to the mononuclear $\left[\mathrm{Cu}^{\mathrm{II}}(\mathrm{OH})\right]^{+}$species anchored on the single framework $\mathrm{Al}$ site at $8 \mathrm{MR}$ position of the $\mathrm{CHA}$ and $\mathrm{AEI}$ cages. ${ }^{2 \mathrm{c}} \mathrm{It}$ is well known that the formation ratio of the $\mathrm{Cu}^{\mathrm{II}}$ species to the $\left[\mathrm{Cu}{ }^{\mathrm{II}}(\mathrm{OH})\right]^{+}$species is sensitive to the $\mathrm{Si} / \mathrm{Al}$ of the zeolite material; the former is selectively generated in the zeolite with the low Si/Al ratio, whereas the latter is selectively generated in the zeolite with the high $\mathrm{Si} / \mathrm{Al}$ ratio. ${ }^{2 c, 3}$ Our results were fully consistent with the previously reported results. Thus, it is no exaggeration to say that our samples are good model catalysts. 


\section{S.2.4. On the Validity of Our Spectroscopic Studies on the Cu Dynamics under the $\mathrm{NH}_{3}-\mathrm{SCR}$}

The data collected in the present study undoubtedly correlate with the previously published $\mathrm{NH}_{3}-\mathrm{SCR}$ mechanism. We monitored the transient fraction of the $\mathrm{Cu}^{\mathrm{II}}$ species upon the $\mathrm{Cu}$ reoxidation process, using the $d-d$ transition band as a spectroscopic probe (Figure S4). The sample was prereduced with 300 ppm NO-300

ppm $\mathrm{NH}_{3}$ at $473 \mathrm{~K}$, and subsequently exposed to $300 \mathrm{ppm} \mathrm{NO}-300 \mathrm{ppm} \mathrm{NH}_{3}-10 \% \mathrm{O}_{2}$. The transient $\mathrm{Cu}^{\mathrm{II}}$ ammine species during the $\mathrm{Cu}^{\mathrm{I}} \rightarrow \mathrm{Cu}^{\mathrm{II}}$ reoxidation process was traced by monitoring the intensity of the $d-d$ transition band at $710 \mathrm{~nm}$ with an interval of 0.5 seconds. As reported by Paolucci et al., the obtained result was found to be possible to explain with the approximation curve of the variation of the transient $\mathrm{Cu}^{\mathrm{II}}$ fraction. ${ }^{1}$ This indicates that our spectroscopic method correctly evaluated the $\mathrm{Cu}$ dynamics that facilitate the $\mathrm{Cu}^{\mathrm{I}} \rightarrow \mathrm{Cu}^{\mathrm{II}}$ reoxidation. The steady-state fraction of the single $\mathrm{Cu}^{\mathrm{II}}$ ammine complex was roughly estimated as 0.93 on the basis of the intensity ratio of the $d-d$ transition bands for the $\mathrm{Cu}^{\mathrm{II}}$ ammine complexes under the $300 \mathrm{ppm} \mathrm{NH}_{3}-$ $300 \mathrm{ppm} \mathrm{NH}-10 \% \mathrm{O}_{2}$ condition and only $300 \mathrm{ppm} \mathrm{NH}_{3}$ gas (Figure S5). The validity of our quantitative analyses was confirmed in the calibration curve, i.e., linear relationship between the intensities of the $d-d$ transition bands for the $\mathrm{Cu}^{\mathrm{II}}$ ammine complexes generated under the $300 \mathrm{ppm} \mathrm{NH}_{3}$ gas at $473 \mathrm{~K}$ and the $\mathrm{Cu}$ loadings (Figure S6).

\section{S.2.5. On the Validity of the DFT Cluster Calculations Using B3LYP Functional}

As reviewed by Solomon et $\mathrm{al},{ }^{4}$ the computational methods to best described the geometric and electronic structures of the model complexes containing the $\mathrm{Cu}_{2} \mathrm{O}_{2}$ core have been calibrated well. According to this review ${ }^{4}$ and related literature, ${ }^{5}$ we used the B3LYP in the present study. Another specific example demonstrating the validity of B3LYP is the calculation of the $\mathrm{CuO}$ molecule. ${ }^{6}$ In this work, B3LYP calculations wellreproduced results of $\mathrm{CCSD}(\mathrm{T})$ of golden standard.

We compared the optimized geometries of $\left(\mu-\eta^{2}: \eta^{2}\right.$-peroxo)dicopper(II) in the present study with the computational results previously reported by Paolucci et al (Figure S12 and Table S3). ${ }^{1}$ The clear difference was found in the geometries of $\left(\mu-\eta^{2}: \eta^{2}\right.$-peroxo)dicopper(II). Paolucci's group reported the square planar geometry of $\left(\mu-\eta^{2}: \eta^{2}\right.$-peroxo)dicopper(II). On the other hand, our model features the butterfly core. Please note that Paolucci et al. used PBE functional. ${ }^{1}$ It is well known that Bandgap or HOMO-LUMO gap becomes smaller for the PBE- 
calculations because PBE-calculation always causes SIC error. This error can be eliminated by including the HF exchange term, so the B3LYP with the exchange term will reduce the SIC error. The same is true for HSE06 and PBE+U with Hubbard $\mathrm{U}$ correction. ${ }^{7}$ It is expected that the PBE results reported by Paolucci's group are incorrect because PBE cannot explain the localization of $\mathrm{d}$ electrons of $\mathrm{Cu}$ in the oxide well. In order to substantiate our claim, we performed geometrical optimizations of $\left(\mu-\eta^{2}: \eta^{2}\right.$-peroxo)dicopper(II) using the PBE or PBE0 functionals (Figure S13). In the PBE-calculation, the square planar geometry of $\left(\mu-\eta^{2}: \eta^{2}-\right.$ peroxo)dicopper(II) was obtained, as the case for the Paolucci's report. On the other hand, the PBE0-calculations that include the HF exchange term provided the butterfly geometry of the $\left(\mu-\eta^{2}: \eta^{2}\right.$-peroxo)dicopper(II), as the case for the B3LYP calculations in the present study. Therefore, the difference between the $\left(\mu-\eta^{2}: \eta^{2}-\right.$ peroxo)dicopper(II) geometries in the present work and previously published Paolucci's paper is derived from the functionals used in the calculations. As described above, the PBE functional is not suitable for calculations on the copper oxygen species encapsulated within the zeolite pore. Thus, we can reasonably claim that our computational results are more justified.

\section{S.2.6. On the Cluster Size Effect on the DFT Cluster Model of $\left(\mu-\eta^{2}: \eta^{2}-\right.$ peroxo)dicopper(II)}

The cluster size effect was also examined (Figure S16), where we expanded the geometry from one AEI cage to two AEI cages. Enormous cluster size dependency was not observed (Table S5). Considering the previous our studies, this "negligible cluster size dependency" is not so surprising. So far, we have intensively studied the novel spectroscopic properties of the isolated metal-oxygen radicals within the zeolite pore: zincozonide, zinc-oxyl, nickel-superoxo, and cobalt-peroxo species. ${ }^{8}$ These species exhibit rarely-known spectroscopic properties: vibronic progressions. The vibronic progression encodes the detailed geometric and electronic structures of the associated species. We recently found that such complicated spectra were reasonably reproduced by DFT cluster calculations using the local structures of the associated species. This is indicative that the spectroscopic property of the metal-oxygen cation within the zeolite pore is not so sensitive to the longrange order structure of the zeolite. Thus, there is considerable validity to the "negligible cluster size dependency" found in the present system. 


\section{S.2.7. On the Spectroscopic Assignment of the UV-Band at $370-350 \mathrm{~nm}$}

One might argue that there are more interpretations possible for the observed UV-Vis-NIR fingerprint. So far, the plausible $\mathrm{Cu}$ species present under the steady-state $\mathrm{NH}_{3}-\mathrm{SCR}$ have been suggested: (1) bare $\mathrm{Cu}^{\mathrm{II}}$; (2) $\left[\mathrm{Cu}^{\mathrm{II}}(\mathrm{OH})\right]^{+}$; (3) linear $\left[\mathrm{Cu}^{\mathrm{I}}\left(\mathrm{NH}_{3}\right)_{2}\right]^{+}$, (4) square planar $\left[\mathrm{Cu}^{\mathrm{II}}\left(\mathrm{NH}_{3}\right)_{4}\right]^{2+},(5)\left[\mathrm{Cu}{ }^{\mathrm{II}}(\mathrm{OH})\left(\mathrm{NH}_{3}\right)_{3}\right]^{+},(6)\left[\mathrm{Cu}\left(\mathrm{NO}_{3}\right)\right]^{+}$ and/or $\left[\mathrm{Cu}\left(\mathrm{NO}_{2}\right)\right]^{+}$, (7) $\left[\mathrm{CuO}_{\mathrm{x}} \mathrm{Cu}\right]^{2+}$. Their reparation procedures were well-established. ${ }^{1,3,9}$ Species (1) can be selectively prepared by thermal activation of the $\mathrm{Cu}$ loaded sample having a low $\mathrm{Si} / \mathrm{Al}$ ratio under $10 \% \mathrm{O}_{2}$ gas. Species (2) can be selectively prepared by thermal activation of the $\mathrm{Cu}$ loaded sample having a high $\mathrm{Si} / \mathrm{Al}$ ratio under $10 \% \mathrm{O}_{2}$ gas. Species (3) can be selectively prepared by the reaction with the $\mathrm{NH}_{3}-\mathrm{NO}$ gas mixture at 473 K. Species (4) can be selectively prepared by the $\mathrm{NH}_{3}$-exposure of the precalcined sample especially having a low Si/Al composition. Species (5) can be selectively prepared by the exposure of the sample having a high $\mathrm{Si} / \mathrm{Al}$ ratio to the $\mathrm{NH}_{3}$ gas. Species (6) can be selectively prepared under the $\mathrm{NO} / \mathrm{O}_{2}$ atmosphere. Species (7) has been suggested to be generated as the transient species under the $\mathrm{NH}_{3}$-SCR condition. According to the literature, we carefully studied UV-Vis-NIR spectra of the sample under the conditions where species (1)-(7) would be generated preferentially (Figure 2). Through these analyses, we found that the $350-370 \mathrm{~nm}$ band is observed only under the $\mathrm{NH}_{3}$-SCR gas mixture. Therefore, we can reasonably exclude the possibilities of the species except for $\left[\mathrm{CuO}_{\mathrm{x}} \mathrm{Cu}\right]^{2+}$ intermediates. It is widely recognized that the dicopper fraction increases with increasing $\mathrm{Cu}$ loading. ${ }^{1,10}$ In this study, a similar trend was also confirmed (Figure S10), which further strengthens our spectroscopic assignment.

Due to the importance of the $\mathrm{Cu}$ oxide intermediates in a variety of the oxidative molecular transformation processes, a considerable number of the model complexes containing a $\mathrm{CuO}_{\mathrm{x}} \mathrm{Cu}$ motif were synthesized so far. Their crystallographic structures led to categorizations of the dicopper intermediates to $\left(\mu-\eta^{1}: \eta^{1}-\right.$ peroxo)dicopper(II), ( $\mu-\eta^{2}: \eta^{2}$-peroxo)dicopper(II), bis( $\mu$-oxo)dicopper(III). These model complexes exhibit the intense and unique spectral features depending on their geometric and electronic structures; thus, UV-Vis-NIR spectroscopy became one of the powerful tools to identify the $\mathrm{CuO}_{\mathrm{x}} \mathrm{Cu}$ species even in zeolite catalyst, as reviewed by Solomon's group. ${ }^{4}$ Based on the data library of the $\mathrm{CuO}_{\mathrm{x}} \mathrm{Cu}$ species reported by Solomon and 
Tolman, ${ }^{4,11}$ we were able to assign the $370-350 \mathrm{~nm}$ band observed in the present study as $\left(\mu-\eta^{2}: \eta^{2}-\right.$ peroxo)dicopper(II).

Our assignment was further supported by DFT cluster calculations as shown in Figure $\mathbf{4}$ in the manuscript. Other types of copper oxygen intermediates, i.e., bis( $\mu$-oxo)dicopper(III), $\left(\mu-\eta^{1}: \eta^{1}-\right.$ peroxo $)$ dicopper(II), $(\mu$ oxo)dicopper(II), were also computationally examined (Figure S17); however, the computationally predicted their UV-Vis features were inconsistent with the experimental data. It was only the $\left(\mu-\eta^{2}: \eta^{2}\right.$-peroxo)dicopper(II) that reasonably accounts for the experimentally observed UV band at 370-350 $\mathrm{nm}$. These results further support our spectroscopic assignment. 


\section{S.3. Supporting Data}

(A)

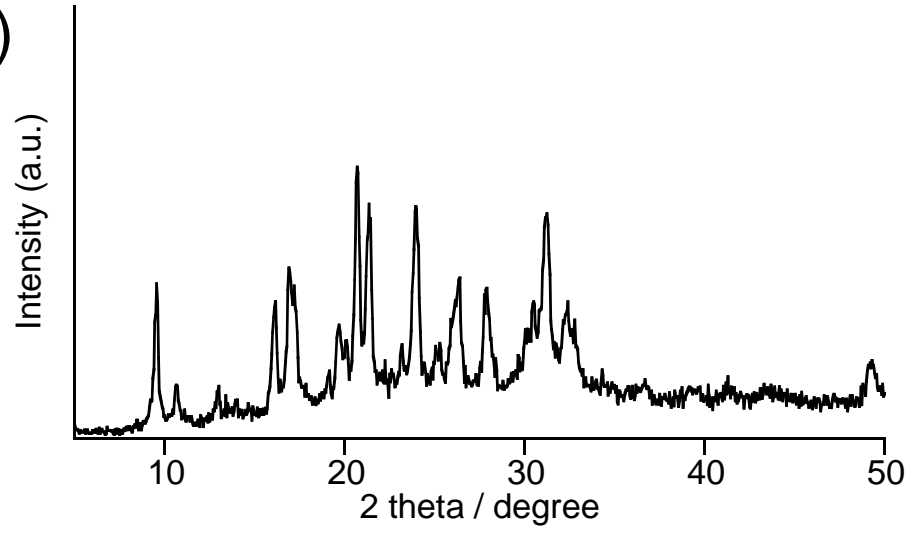

(B)

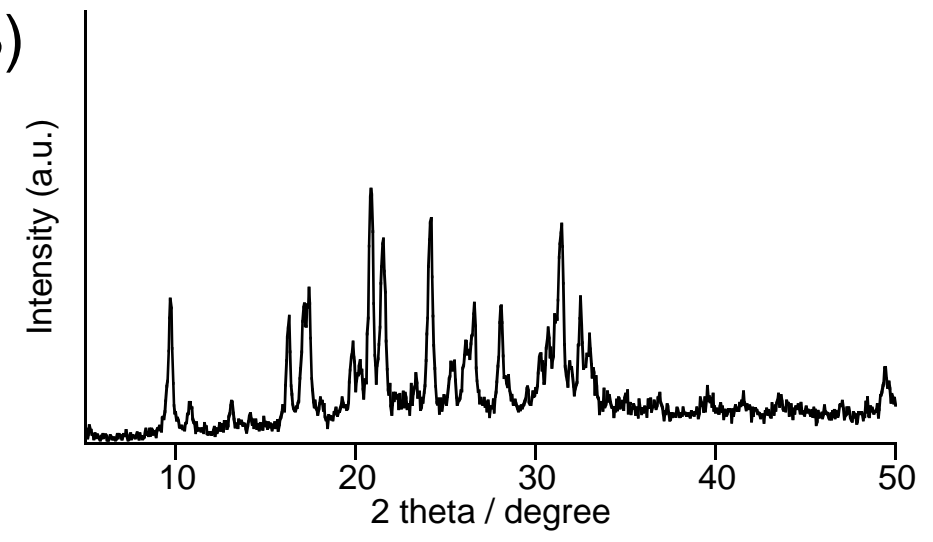

(C)

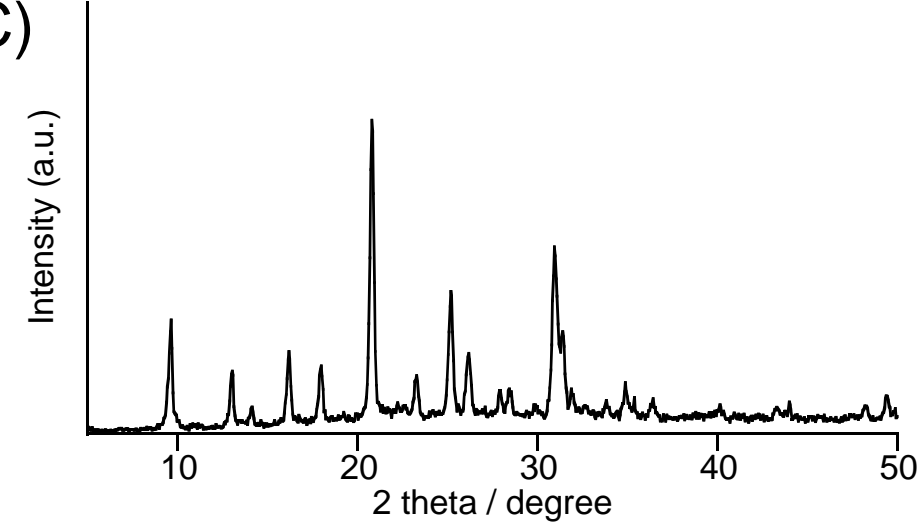

Figure S1. XRD profiles of the samples: (A) Cu/AEI (5.5, 3.4); (B) Cu/AEI (10, 3.4); (C) $\mathrm{Cu} / \mathrm{CHA}(12,3.2)$. 


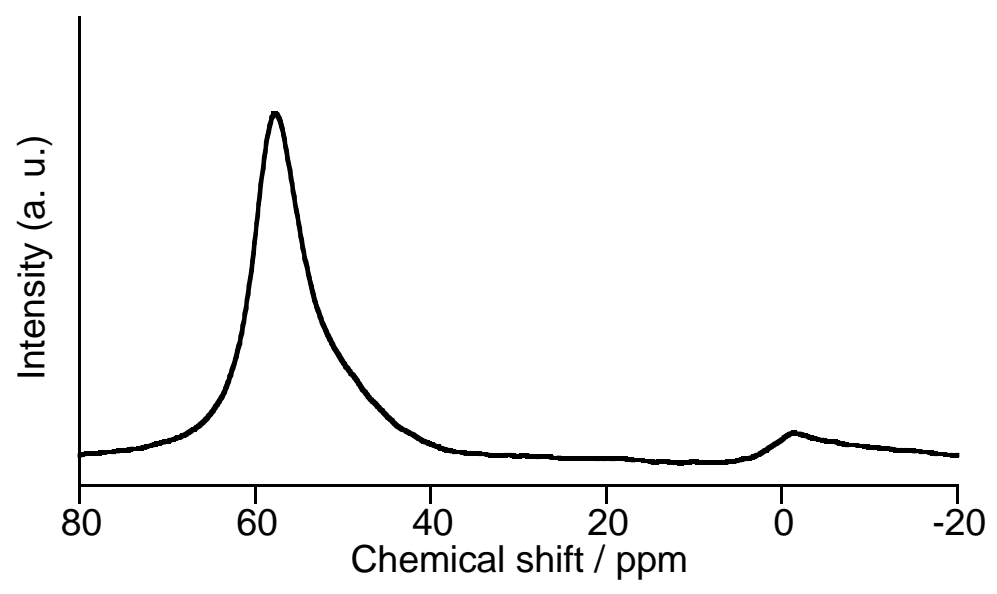

Figure S2. ${ }^{27} \mathrm{Al}$ MAS NMR data of the Cu/AEI $(3.4,5.5)$ sample. 
(A)

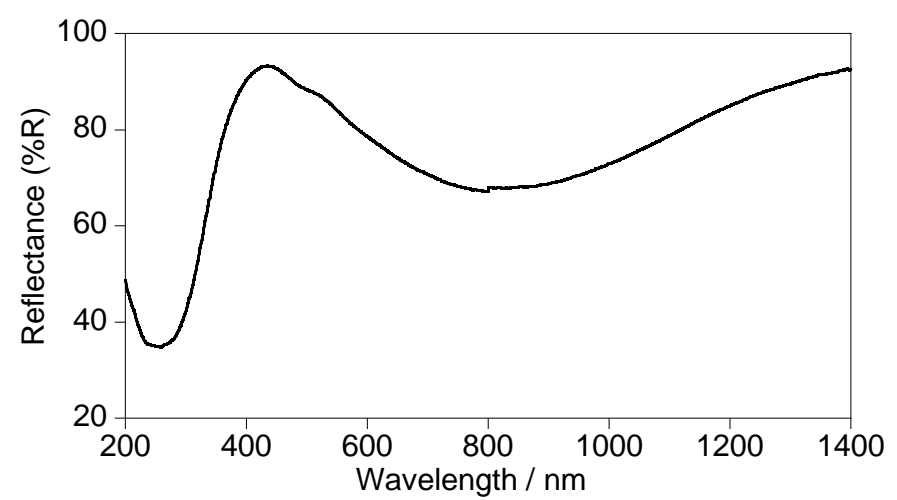

(B)

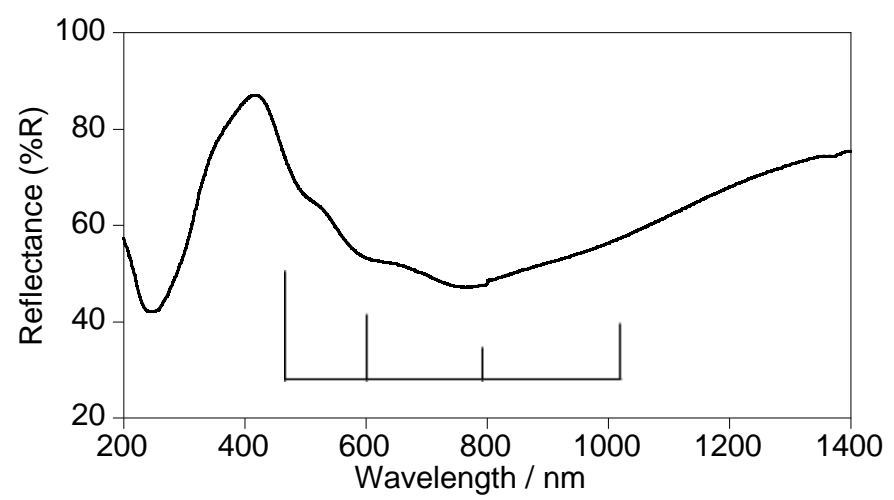

(C)

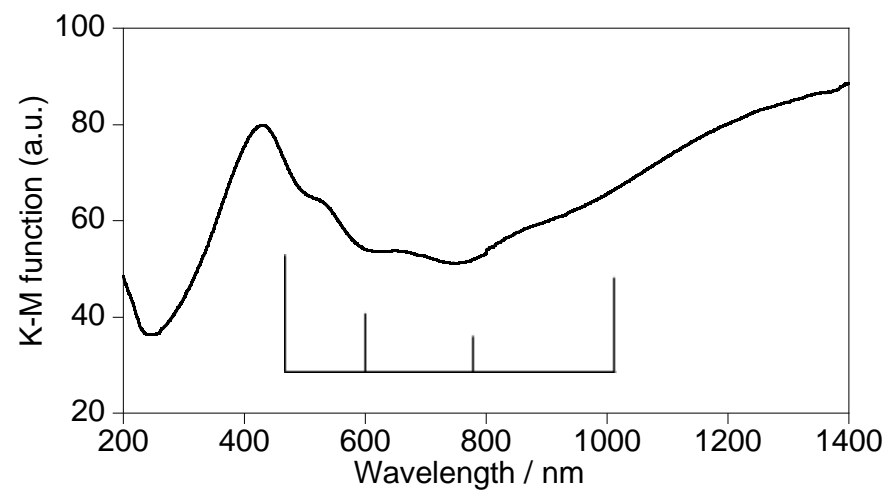

Figure S3. In situ UV-Vis-NIR spectra of the samples precalcined with $10 \% \mathrm{O}_{2}$ at $773 \mathrm{~K}$ : (A) $\mathrm{Cu} / \mathrm{AEI}$ (5.5, 3.4); (B) $\mathrm{Cu} / \mathrm{AEI}(10,3.4)$; (C) $\mathrm{Cu} / \mathrm{CHA}(12,3.2)$. All spectra were collected at $473 \mathrm{~K}$ under Ar flow. 
(A)

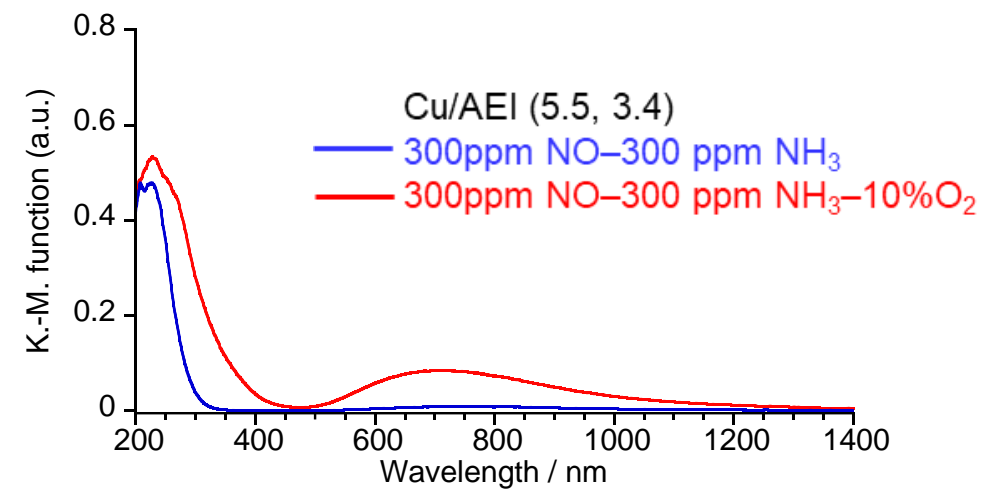

(B)

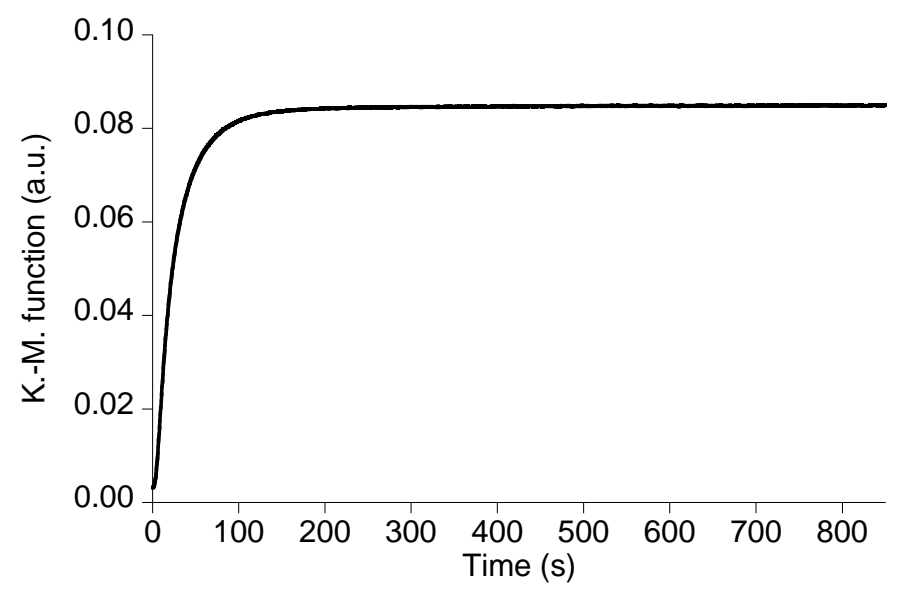

Figure S4. UV-Vis-NIR study on the kinetic of $\mathrm{Cu}^{\mathrm{I}} \rightarrow \mathrm{Cu}^{\mathrm{II}}$ reoxidation by $\mathrm{O}_{2}$. The sample was prereduced by 300 ppm NO-300 ppm $\mathrm{NH}_{3}$ at $473 \mathrm{~K}$. Subsequently, $10 \% \mathrm{O}_{2}$ was introduced into to the present system. (A) UV-Vis-NIR spectra of the $\mathrm{Cu} / \mathrm{AEI}(5.5,3.4)$ sample before and after the reoxidation of $\mathrm{Cu}^{\mathrm{I}}$ to $\mathrm{Cu}^{\mathrm{II}}$. (B) Change in the intensity of the $d-d$ transition band at $710 \mathrm{~nm}$ of the $\mathrm{Cu}^{\mathrm{II}}$ ammine complex during the transient oxidation in $10 \% \mathrm{O}_{2}$. Intensities were recorded with an interval of 0.5 seconds. 

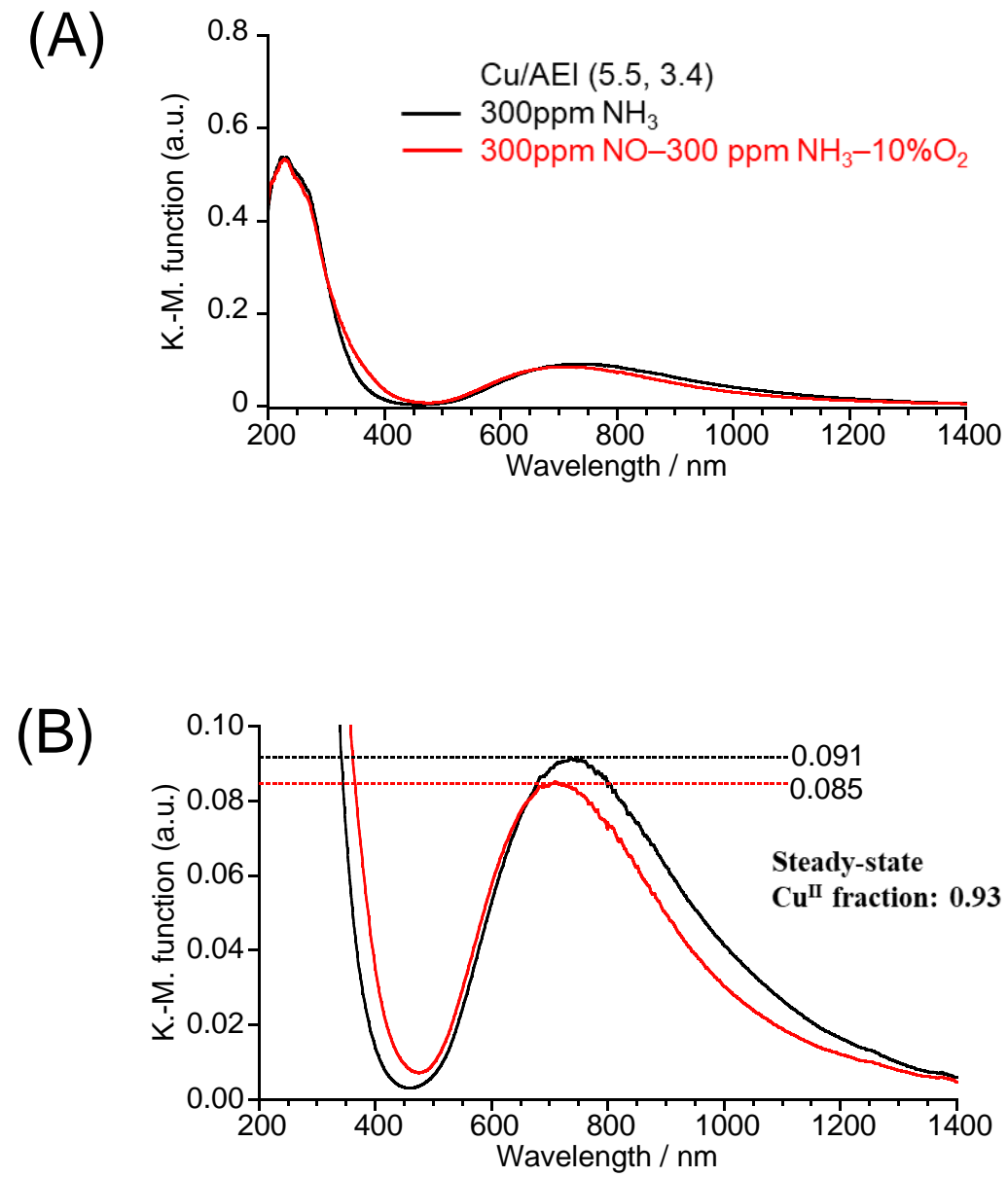

Figure S5. (A) UV-Vis-NIR spectra of the $\mathrm{Cu} / \mathrm{AEI}(5.5,3.4)$ sample under the $300 \mathrm{ppm} \mathrm{NH}_{3}$ and $300 \mathrm{ppm} \mathrm{NO}$ $300 \mathrm{ppm} \mathrm{NH}_{3}-10 \% \mathrm{O}_{2}$ at $473 \mathrm{~K}$. (B) Enlarged graph, where intensities of the $d$ - $d$ transition bands for the $\mathrm{Cu}^{\mathrm{II}}$ ammine complexes are indicated. 
(A)
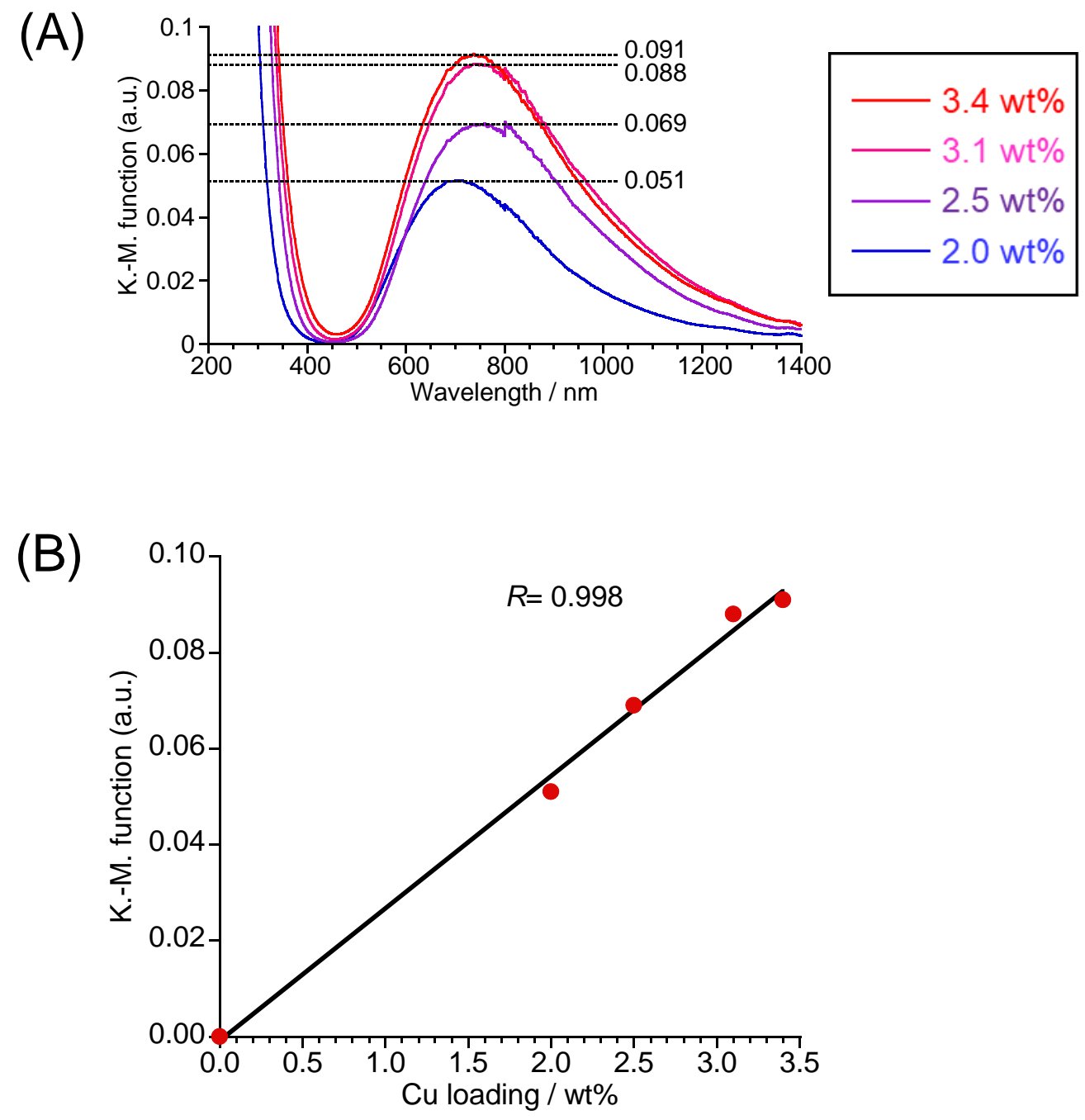

Figure S6. (A) In situ UV-Vis-NIR spectra of the Cu/AEI sample with $\mathrm{Si} / \mathrm{Al}=5.5$ and $\mathrm{Cu}$ loading of $2.0 \mathrm{st} \%$, $2.5 \mathrm{wt} \%, 3.1 \mathrm{wt} \%$, and $3.4 \mathrm{wt} \%$ under the $300 \mathrm{ppm} \mathrm{NH}_{3}$ at $473 \mathrm{~K}$, where the intensities of the $d-d$ transition bands for the $\mathrm{Cu}^{\mathrm{II}}$ ammine complexes were also given. All spectra were collected in situ at $473 \mathrm{~K}$. (B) A plot of the intensity of the $d-d$ transition bands for the $\mathrm{Cu}^{\mathrm{II}}$ ammine complexes with the $\mathrm{Cu}$ loadings. 


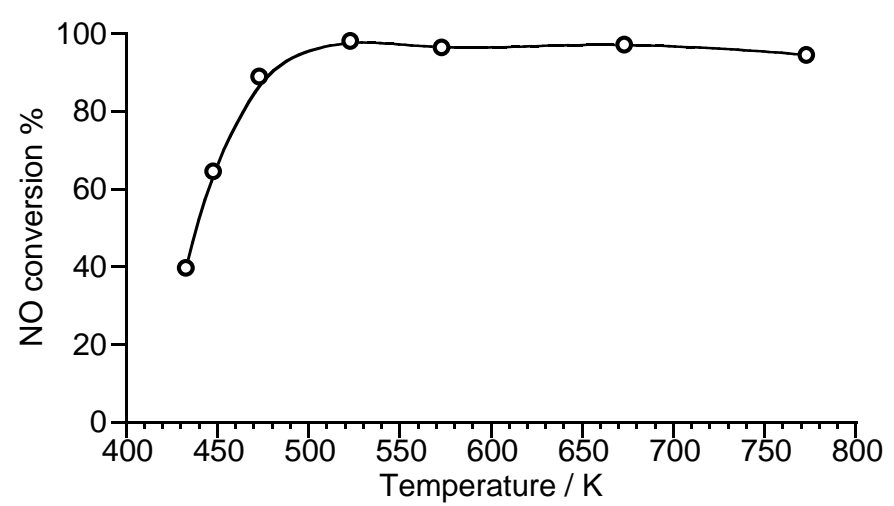

Figure S7. Catalytic reactivity of the Cu/AEI $(5.5,3.4)$ sample. Reaction condition: $\mathrm{SV}=200000 \mathrm{~h}^{-1} ; 350 \mathrm{ppm}$ $\mathrm{NH}_{3}-385 \mathrm{ppm} \mathrm{NH}-15 \% \mathrm{O}_{2}-5 \% \mathrm{H}_{2} \mathrm{O}\left(\mathrm{N}_{2}\right.$ balance $)$. 

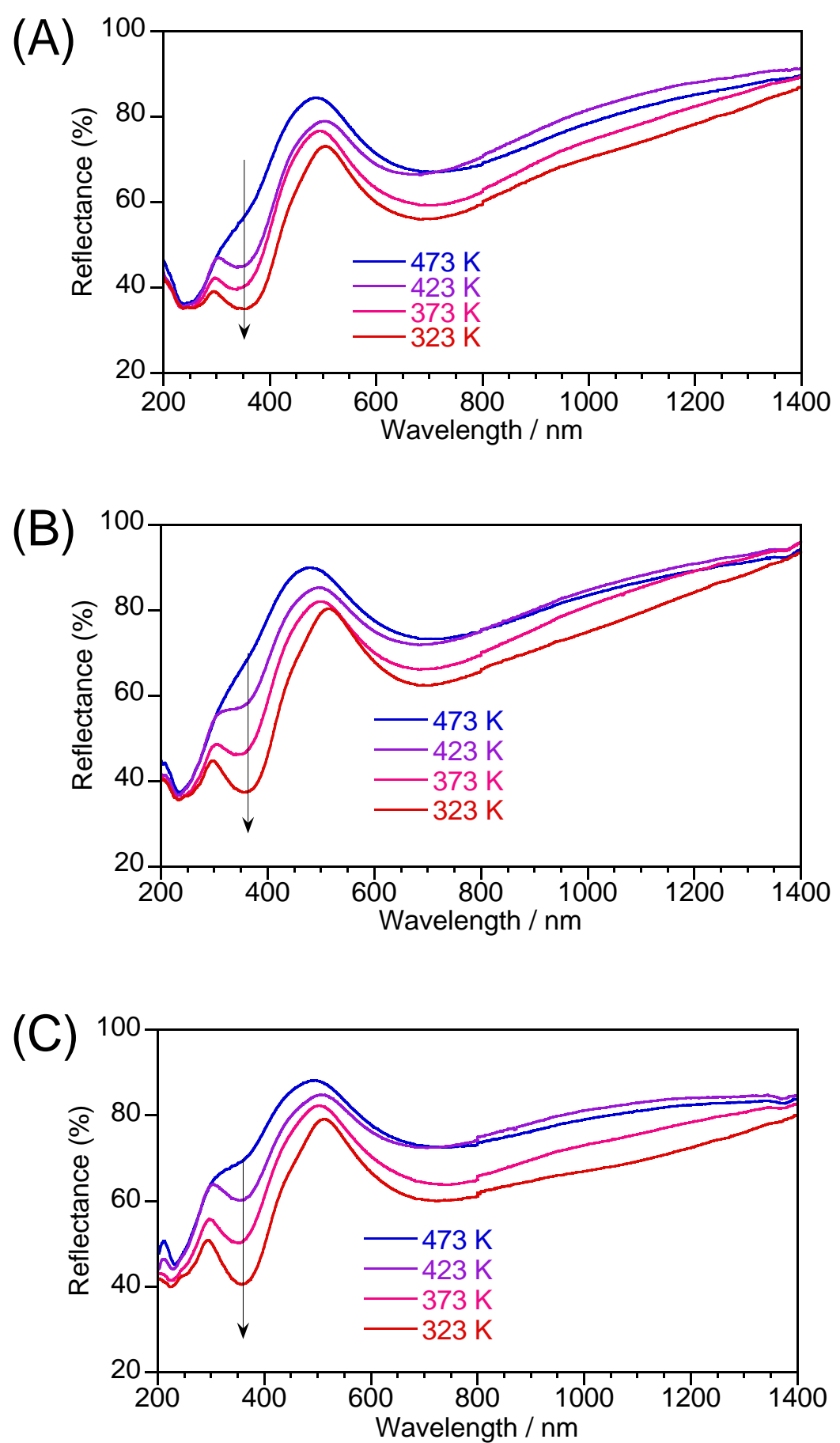

Figure S8. In situ UV-Vis-NIR spectra of the (A) Cu/AEI (5.5, 3.4), (B) $\mathrm{Cu} / \mathrm{CHA}(12,3.2)$, and (C) Cu/AEI $(10,3.4)$ samples under the $1000 \mathrm{ppm} \mathrm{NO}-1000 \mathrm{ppm} \mathrm{NH} \mathrm{NH}_{3}-10 \% \mathrm{O}_{2}$ at $473-323 \mathrm{~K}$. All spectra were collected under the $\mathrm{NH}_{3}$-SCR gas mixtures at respective temperatures. 
(A)

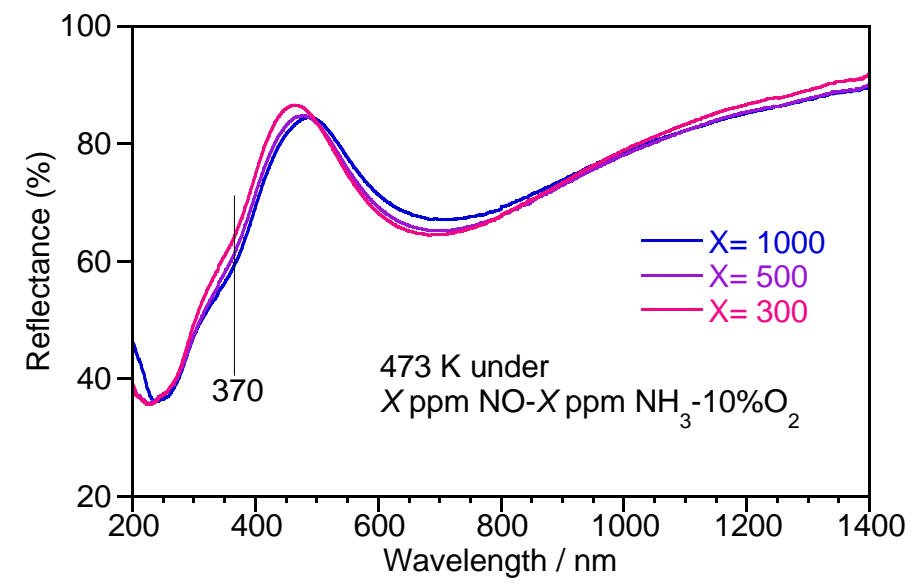

(B)

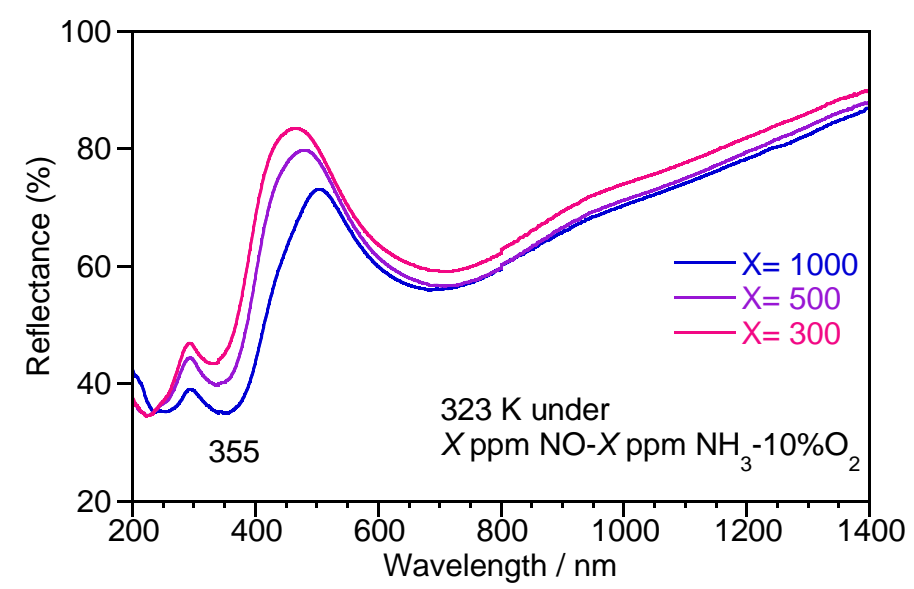

Figure S9. In situ UV-Vis-NIR spectra of the $\mathrm{Cu} / \mathrm{AEI}(5.5,3.4)$ sample under the $X \mathrm{ppm} \mathrm{NO}-X \mathrm{ppm} \mathrm{NH}_{3}-10 \%$ $\mathrm{O}_{2}(\mathrm{X}=1000,500$, or 300$)$ at (A) $473 \mathrm{~K}$ and (B) $323 \mathrm{~K}$. All spectra were collected under the respective conditions. 


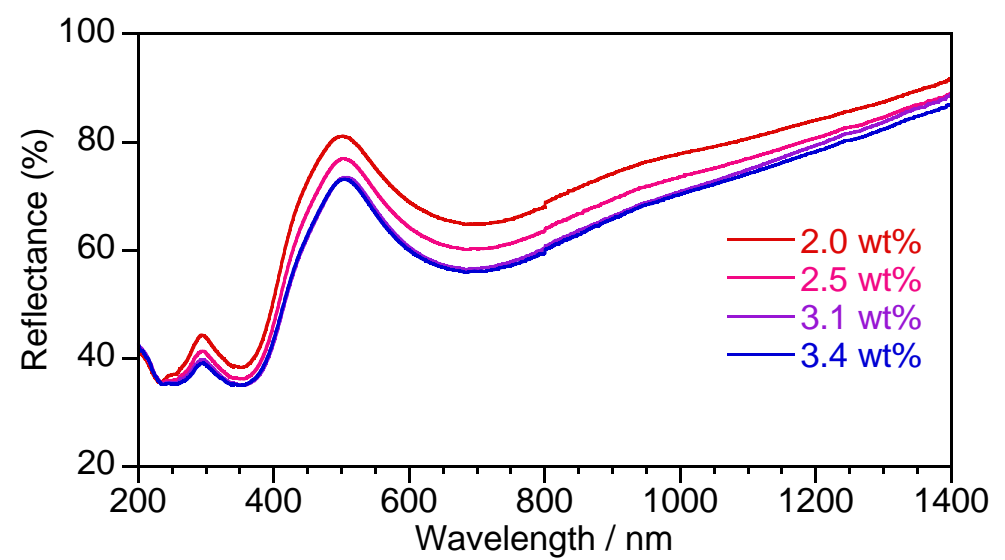

Figure S10. In situ UV-Vis-NIR spectra of the Cu/AEI sample with $\mathrm{Si} / \mathrm{Al}=5.5$ and $\mathrm{Cu}$ loading of $2.0 \mathrm{st} \%, 2.5$ $\mathrm{wt} \%, 3.1 \mathrm{wt} \%$, and $3.4 \mathrm{wt} \%$ under the $1000 \mathrm{ppm} \mathrm{NO}-1000 \mathrm{ppm} \mathrm{NH}_{3}-10 \% \mathrm{O}_{2}$ gas mixture at $323 \mathrm{~K}$. All spectra were collected in situ at $323 \mathrm{~K}$. 

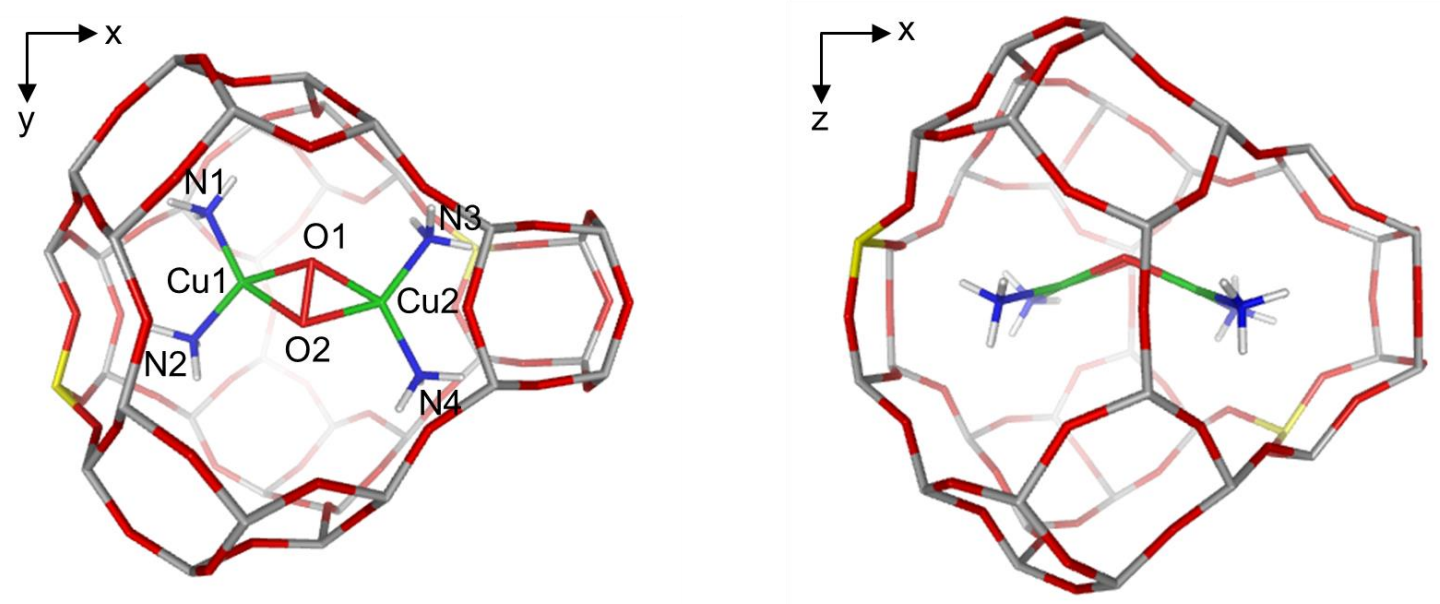

Figure S11. Enlarged graphs for the optimized geometry of $\left[\mathrm{Cu}_{2} \mathrm{O}_{2}\left(\mathrm{NH}_{3}\right)_{4}\right]-\mathrm{Al}_{2} \mathrm{Si}_{34} \mathrm{O}_{54} \mathrm{H}_{36}$ shown in Figure 3 in the manuscript. For clarity, the model was depicted in a wireframe style. The selective geometrical parameters and the calculated Mulliken spin densities are summarized in Tables S1 and S2, respectively. Legend: green, $\mathrm{Cu}$; blue, N; white, $\mathrm{H}$; yellow, $\mathrm{Al}$; gray, $\mathrm{Si}$; red, $\mathrm{O}$. 
Table S1. Selective structural parameters of the model shown in Figure S11.

$\begin{array}{cc}\begin{array}{c}\text { Distance }(\AA) \text { or bond } \\ \text { angle (deg) }\end{array} & \left(\boldsymbol{\mu}-\boldsymbol{\eta}^{2}: \boldsymbol{\eta}^{2} \text {-peroxo)dicopper(II) }\right. \\ \mathrm{Cu} 1-\mathrm{Cu} 2 & 3.379 \\ \mathrm{O} 1-\mathrm{O} 2 & 1.451 \\ \mathrm{Cu} 1-\mathrm{O} 1 & 1.957 \\ \mathrm{Cu} 1-\mathrm{O} 2 & 1.971 \\ \mathrm{Cu} 2-\mathrm{O} 1 & 1.976 \\ \mathrm{Cu} 2-\mathrm{O} 2 & 1.978 \\ \mathrm{Cu} 1-\mathrm{N} 1 & 2.025 \\ \mathrm{Cu} 1-\mathrm{N} 2 & 1.975 \\ \mathrm{Cu} 2-\mathrm{N} 3 & 1.982 \\ \mathrm{Cu} 2-\mathrm{N} 4 & 2.016 \\ \angle \mathrm{O} 1-\mathrm{Cu} 1-\mathrm{O} 2 & 43.4 \\ \angle \mathrm{O} 1-\mathrm{Cu} 2-\mathrm{O} 2 & 43.1\end{array}$


Table S2. Calculated Mulliken spin densities of the model shown in Figure S11. A positive value means $\alpha$ spin density; a negative value means $\beta$-spin density.

$\begin{array}{cc}\text { Mulliken spin densities } & \left(\boldsymbol{\mu}-\boldsymbol{\eta}^{2}: \boldsymbol{\eta}^{2} \text {-peroxo }\right) \text { dicopper(II) } \\ \text { Cu1 } & -0.44 \\ \mathrm{Cu} 2 & 0.44 \\ \mathrm{O} 1 & 0.01 \\ \mathrm{O} 2 & -0.01 \\ \mathrm{~N} 1 & -0.07 \\ \mathrm{~N} 2 & -0.08 \\ \mathrm{~N} 3 & 0.07 \\ \mathrm{~N} 4 & 0.09\end{array}$




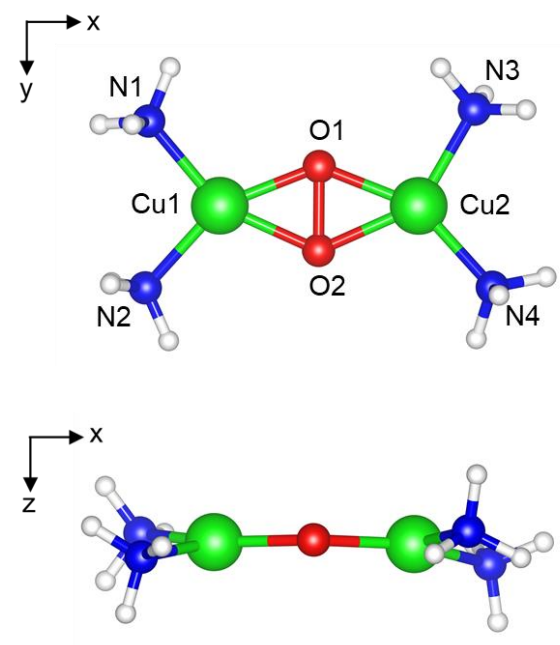

Figure S12. Local geometries of $\left(\mu-\eta^{2}: \eta^{2}\right.$-peroxo)dicopper(II), which was reported in Ref. 1. Legend: green, $\mathrm{Cu}$; blue, N; white, $\mathrm{H}$; red, $\mathrm{O}$. 
Table S3. Selected DFT parameters of the model shown in Figure S12. For comparison, our computational results were also given.

\begin{tabular}{ccc}
\hline $\begin{array}{c}\text { Distance }(\mathbf{\AA}), \text { bond angle }(\mathbf{d e g}), \\
\text { dihedral angle }(\mathbf{d e g}), \text { or relative } \\
\text { energy }\left(\mathbf{k J ~ m o l} \mathbf{~}^{-1}\right)\end{array}$ & Present work & Ref. 1 \\
\hline $\mathrm{Cu} 1-\mathrm{Cu} 2$ & 3.379 & 3.528 \\
$\mathrm{O} 1-\mathrm{O} 2$ & 1.451 & 1.487 \\
$\mathrm{Cu} 1-\mathrm{O} 1$ & 1.957 & 1.922 \\
$\mathrm{Cu} 1-\mathrm{O} 2$ & 1.971 & 1.895 \\
$\mathrm{Cu} 2-\mathrm{O} 1$ & 1.976 & 1.947 \\
$\mathrm{Cu} 2-\mathrm{O} 2$ & 1.978 & 1.900 \\
$\mathrm{Cu} 1-\mathrm{N} 1$ & 2.025 & 1.979 \\
$\mathrm{Cu} 1-\mathrm{N} 2$ & 1.975 & 1.980 \\
$\mathrm{Cu} 2-\mathrm{N} 3$ & 1.982 & 1.974 \\
$\mathrm{Cu} 2-\mathrm{N} 4$ & 2.016 & 1.988 \\
$\angle \mathrm{O} 1-\mathrm{Cu} 1-\mathrm{O} 2$ & 43.4 & 45.9 \\
$\angle \mathrm{O} 1-\mathrm{Cu} 2-\mathrm{O} 2$ & 43.1 & 45.5 \\
$\angle \mathrm{Cu} 1-\mathrm{O} 1-\mathrm{O} 2-\mathrm{Cu} 2$ & 134.5 & 176.4
\end{tabular}


PBE functional
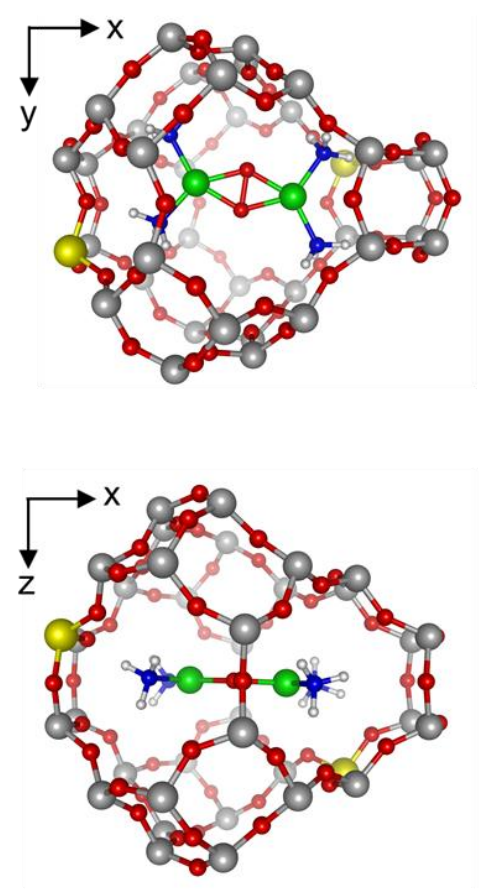

Square planar
PBE0 functional
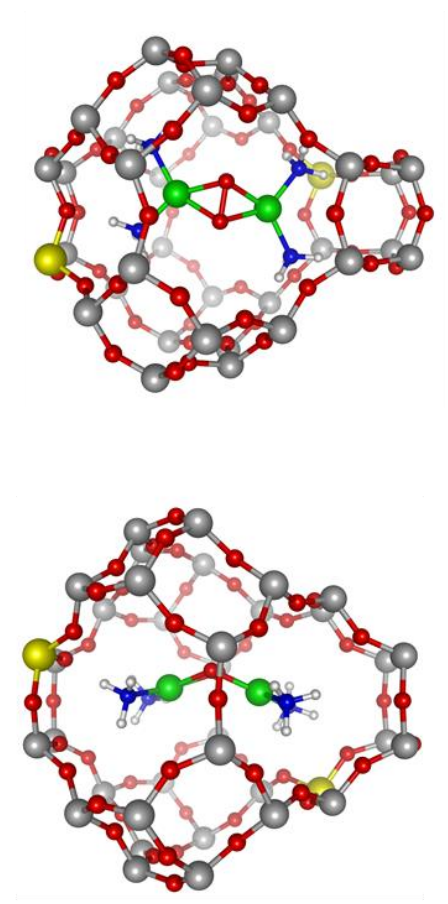

Butterfly
B3LYP functional
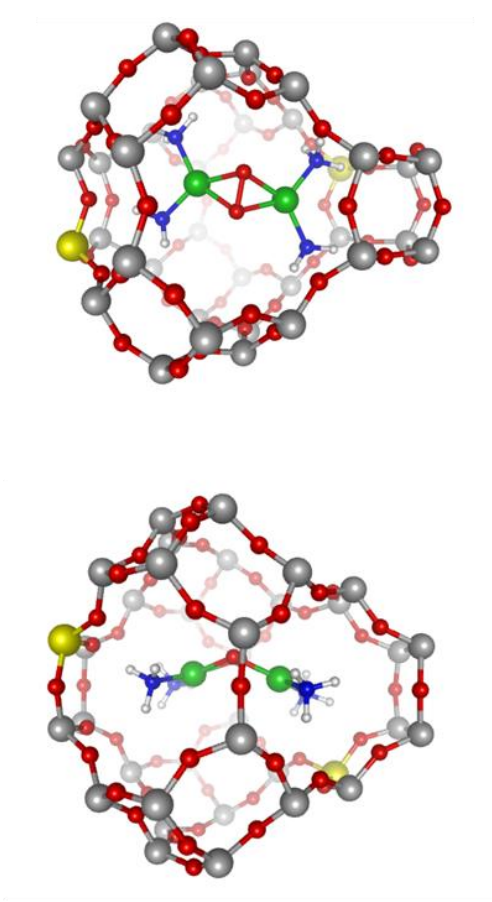

Butterfly

Figure S13. Comparison of the models of $\left(\mu-\eta^{2}: \eta^{2}\right.$-peroxo)dicopper(II) that were optimized using PBE, PBE0, or B3LYP functionals with the 6-311+G(d,p) basis set for $\mathrm{Cu}, \mathrm{O}_{2}$, and $\mathrm{NH}_{3}$, and 6-31G(d) basis set for remaining atoms. Legend: green, $\mathrm{Cu}$; blue, $\mathrm{N}$; white, $\mathrm{H}$; yellow, $\mathrm{Al}$; gray, $\mathrm{Si}$; red, O. 
Al configuration 1

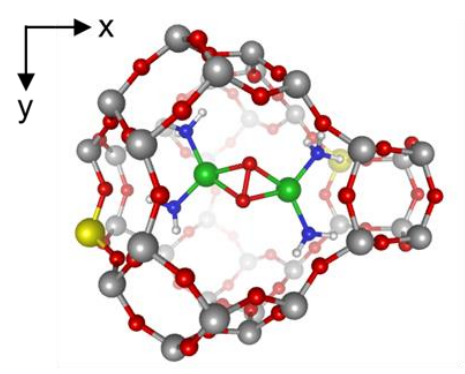

$\longrightarrow$

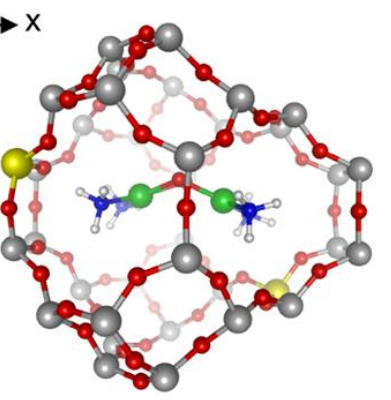

Al configuration 4
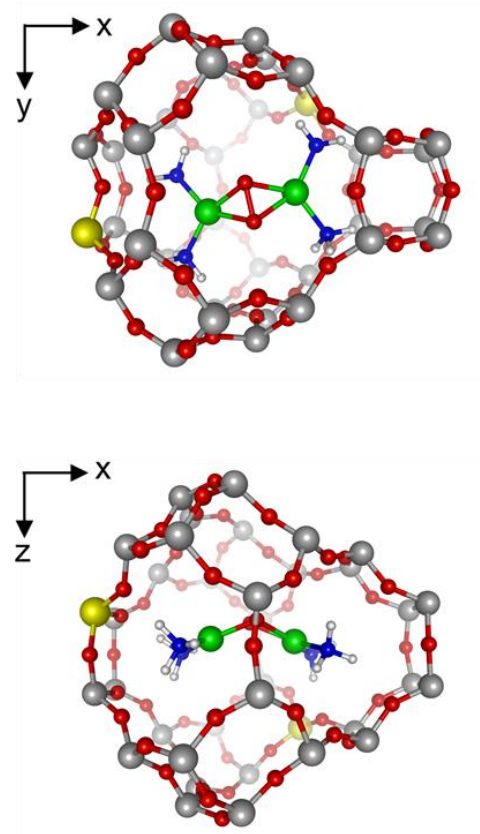

Al configuration 2
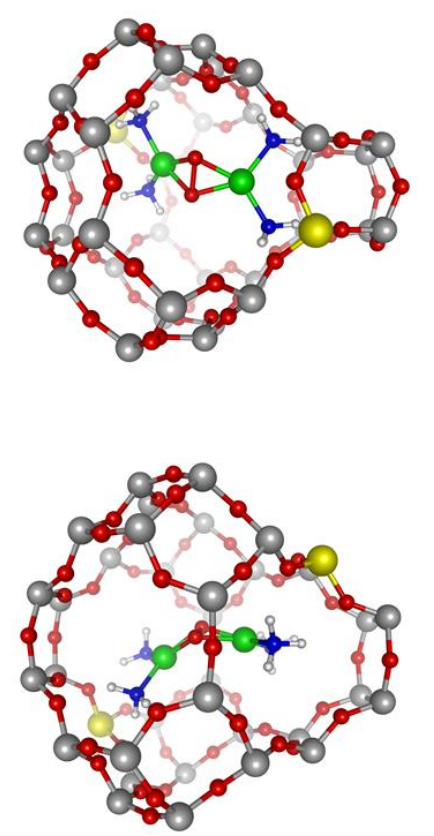

Al configuration 5
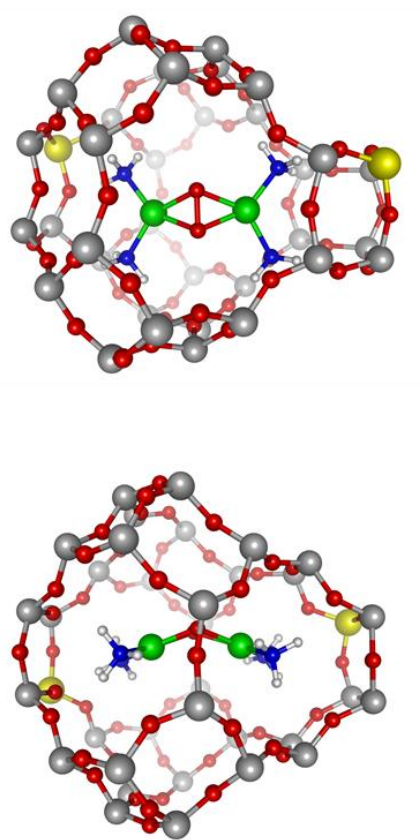

Al configuration 3
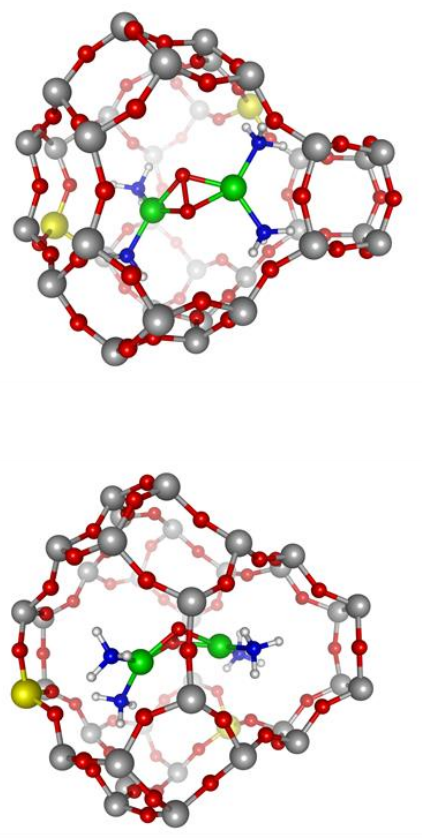

Al configuration 6
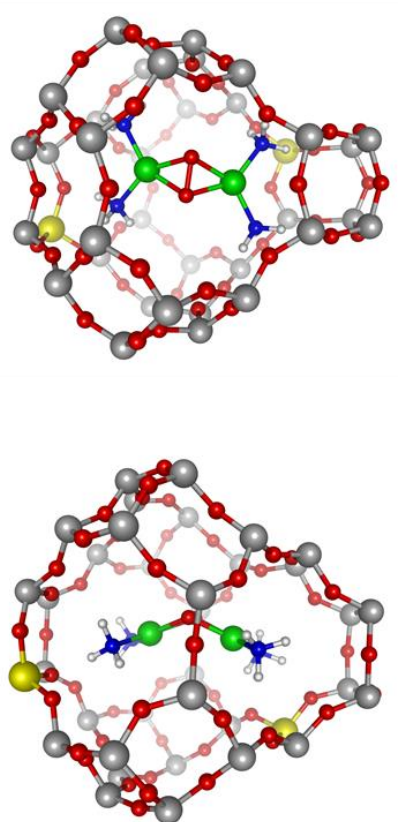

Figure S14. Optimized DFT cluster models of $\left(\mu-\eta^{2}: \eta^{2}\right.$-peroxo)dicopper(II) encapsulated within the AEI cage having different $\mathrm{Al}$ configurations. Legend: green, $\mathrm{Cu}$; blue, $\mathrm{N}$; white, $\mathrm{H}$; yellow, $\mathrm{Al}$; gray, $\mathrm{Si}$; red, $\mathrm{O}$. 

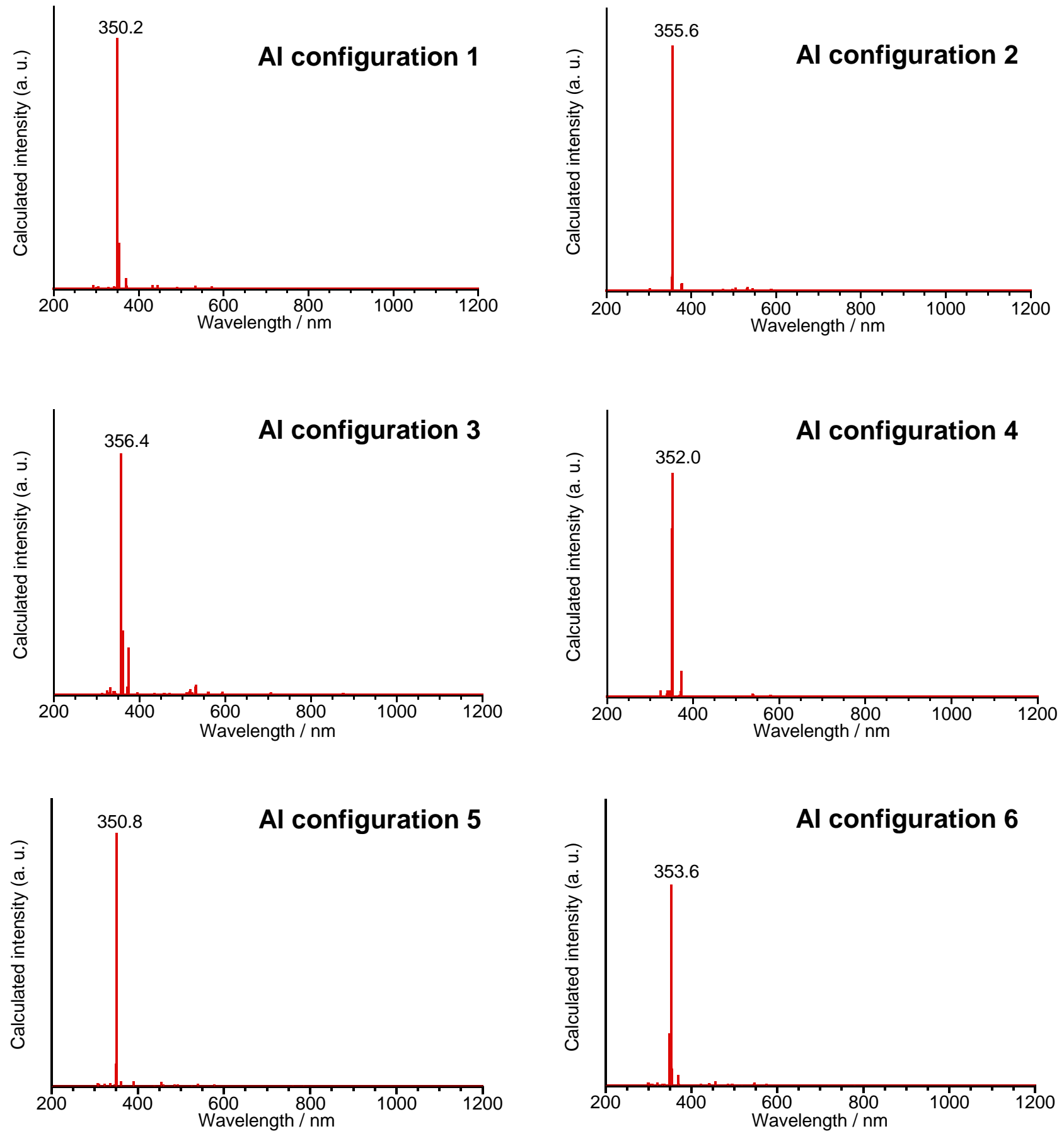

Figure S15. Computed UV-Vis-NIR spectra of the models of $\left(\mu-\eta^{2}: \eta^{2}\right.$-peroxo)dicopper(II) encapsulated within the AEI cage having different $\mathrm{Al}$ configurations $\left(\mathrm{FWHM}=10 \mathrm{~cm}^{-1}\right)$. Legend: green, $\mathrm{Cu}$; blue, $\mathrm{N}$; white, $\mathrm{H}$; yellow, Al; gray, Si; red, O. 
Table S4. Selected DFT parameters of the models shown in Figure S14.

\begin{tabular}{|c|c|c|c|c|c|c|}
\hline $\begin{array}{c}\text { Distance }(\AA), \\
\text { bond angle }(\mathrm{deg}), \\
\text { dihedral angle }(\mathrm{deg}), \\
\lambda_{\text {MAX }}(\mathrm{nm}), \text { relative } \\
\text { energy }\left(\mathrm{kJ} \mathrm{mol}^{-1}\right)\end{array}$ & 1 & 2 & 3 & 4 & 5 & 6 \\
\hline $\mathrm{Cu} 1-\mathrm{Cu} 2$ & 3.379 & 3.392 & 3.341 & 3.367 & 3.450 & 3.375 \\
\hline $\mathrm{O} 1-\mathrm{O} 2$ & 1.451 & 1.450 & 1.444 & 1.448 & 1.451 & 1.449 \\
\hline $\mathrm{Cu} 1-\mathrm{O} 1$ & 1.957 & 1.997 & 1.963 & 1.965 & 1.951 & 1.963 \\
\hline $\mathrm{Cu} 1-\mathrm{O} 2$ & 1.971 & 1.948 & 1.997 & 1.973 & 1.976 & 1.976 \\
\hline $\mathrm{Cu} 2-\mathrm{O} 1$ & 1.976 & 1.979 & 1.999 & 1.979 & 1.967 & 1.982 \\
\hline $\mathrm{Cu} 2-\mathrm{O} 2$ & 1.978 & 1.984 & 1.969 & 1.980 & 1.989 & 1.977 \\
\hline $\mathrm{Cu} 1-\mathrm{N} 1$ & 2.025 & 2.000 & 1.974 & 1.976 & 1.977 & 2.021 \\
\hline $\mathrm{Cu} 1-\mathrm{N} 2$ & 1.975 & 1.991 & 2.007 & 1.998 & 2.028 & 1.979 \\
\hline $\mathrm{Cu} 2-\mathrm{N} 3$ & 1.982 & 2.014 & 1.998 & 1.997 & 1.995 & 1.982 \\
\hline $\mathrm{Cu} 2-\mathrm{N} 4$ & 2.016 & 1.998 & 2.039 & 2.024 & 2.014 & 2.017 \\
\hline$\angle \mathrm{O} 1-\mathrm{Cu} 1-\mathrm{O} 2$ & 43.4 & 43.1 & 42.8 & 43.1 & 43.3 & 43.2 \\
\hline$\angle \mathrm{O} 1-\mathrm{Cu} 2-\mathrm{O} 2$ & 43.1 & 42.9 & 42.7 & 42.9 & 43.0 & 42.9 \\
\hline$\angle \mathrm{Cu} 1-\mathrm{O} 1-\mathrm{O} 2-\mathrm{Cu} 2$ & 134.5 & 134.4 & 129.6 & 132.9 & 140.6 & 133.4 \\
\hline $\mathrm{Al}-\mathrm{Al}$ & 11.66 & 11.92 & 9.73 & 10.75 & 12.76 & 10.71 \\
\hline$\lambda_{\mathrm{MAX}}$ & 350.2 & 355.6 & 356.4 & 352.0 & 350.8 & 353.6 \\
\hline Relative energy $^{a}$ & 0 & -29.8 & -1.0 & +6.4 & +15.8 & -3.9 \\
\hline
\end{tabular}

${ }^{a}$ Relative energies were calculated based on the energy of the model having an Al configuration 1. 

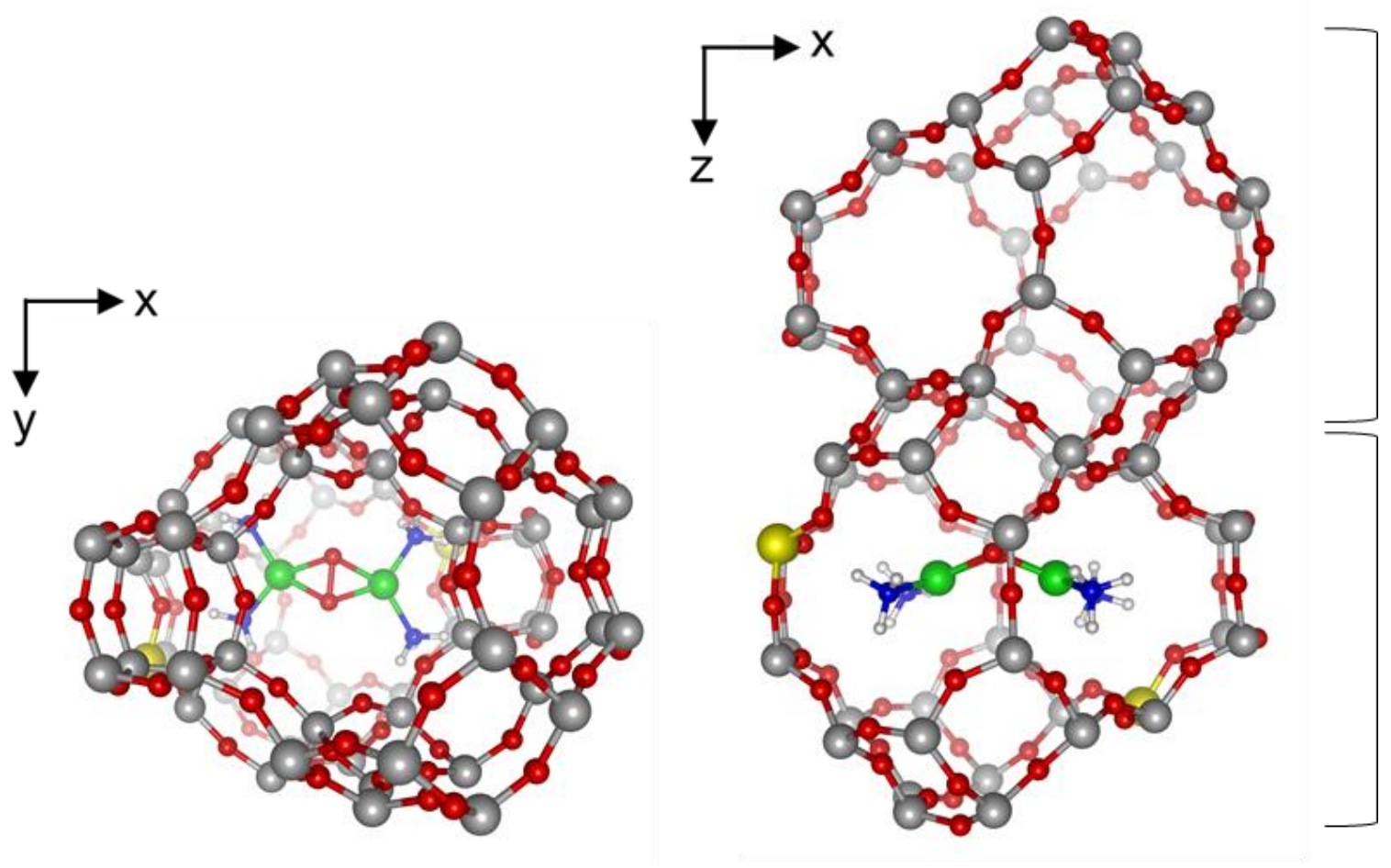

Figure S16. Extended models of $\left(\mu-\eta^{2}: \eta^{2}\right.$-peroxo)dicopper(II) encapsulated within the AEI cage: $\left[\mathrm{Cu}_{2} \mathrm{O}_{2} \mathrm{~N}_{4} \mathrm{H}_{12}\right]$ $\mathrm{Al}_{2} \mathrm{Si}_{62} \mathrm{O}_{100} \mathrm{H}_{56}$. Legend: green, $\mathrm{Cu}$; blue, $\mathrm{N}$; white, $\mathrm{H}$; yellow, $\mathrm{Al}$; gray, Si; red, O. 
Table S5. Selected DFT parameters of the models shown in Figure S16. For comparison, the smaller cluster model $\left(\left[\mathrm{Cu}_{2} \mathrm{O}_{2} \mathrm{~N}_{4} \mathrm{H}_{12}\right]-\mathrm{Al}_{2} \mathrm{Si}_{34} \mathrm{O}_{54} \mathrm{H}_{36}\right.$ : Figure 3 in the main text) was also given.

\begin{tabular}{|c|c|c|}
\hline $\begin{array}{c}\text { Distance }(\AA), \text { bond angle }(\mathrm{deg}), \text { dihedral } \\
\text { angle }(\mathrm{deg}), \lambda_{\operatorname{MAx}}(\mathrm{nm}) \text { or relative } \\
\text { energy }\left(\mathrm{kJ} \mathrm{mol}^{-1}\right)\end{array}$ & $\begin{array}{c}1 \text { cage } \\
{\left[\mathrm{Cu}_{2} \mathrm{O}_{2} \mathrm{~N}_{4} \mathrm{H}_{12}\right]-\mathrm{Al}_{2} \mathrm{Si}_{34} \mathrm{O}_{54} \mathrm{H}_{36}}\end{array}$ & $\begin{array}{c}2 \text { cage } \\
{\left[\mathrm{Cu}_{2} \mathrm{O}_{2} \mathrm{~N}_{4} \mathrm{H}_{12}\right]-\mathrm{Al}_{2} \mathrm{Si}_{62} \mathrm{O}_{100} \mathrm{H}_{56}}\end{array}$ \\
\hline $\mathrm{Cu} 1-\mathrm{Cu} 2$ & 3.379 & 3.392 \\
\hline $\mathrm{O} 1-\mathrm{O} 2$ & 1.451 & 1.450 \\
\hline $\mathrm{Cu} 1-\mathrm{O} 1$ & 1.957 & 1.997 \\
\hline $\mathrm{Cu} 1-\mathrm{O} 2$ & 1.971 & 1.948 \\
\hline $\mathrm{Cu} 2-\mathrm{O} 1$ & 1.976 & 1.979 \\
\hline $\mathrm{Cu} 2-\mathrm{O} 2$ & 1.978 & 1.984 \\
\hline $\mathrm{Cu} 1-\mathrm{N} 1$ & 2.025 & 2.022 \\
\hline $\mathrm{Cu} 1-\mathrm{N} 2$ & 1.975 & 1.976 \\
\hline $\mathrm{Cu} 2-\mathrm{N} 3$ & 1.982 & 1.981 \\
\hline $\mathrm{Cu} 2-\mathrm{N} 4$ & 2.016 & 2.016 \\
\hline$\angle \mathrm{O} 1-\mathrm{Cu} 1-\mathrm{O} 2$ & 43.4 & 43.4 \\
\hline$\angle \mathrm{O} 1-\mathrm{Cu} 2-\mathrm{O} 2$ & 43.1 & 43.1 \\
\hline$\angle \mathrm{Cu} 1-\mathrm{O} 1-\mathrm{O} 2-\mathrm{Cu} 2$ & 134.5 & 135.0 \\
\hline $\mathrm{Al}-\mathrm{Al}$ & 11.66 & 11.92 \\
\hline$\lambda_{\mathrm{MAX}}$ & 350.2 & 350.8 \\
\hline
\end{tabular}



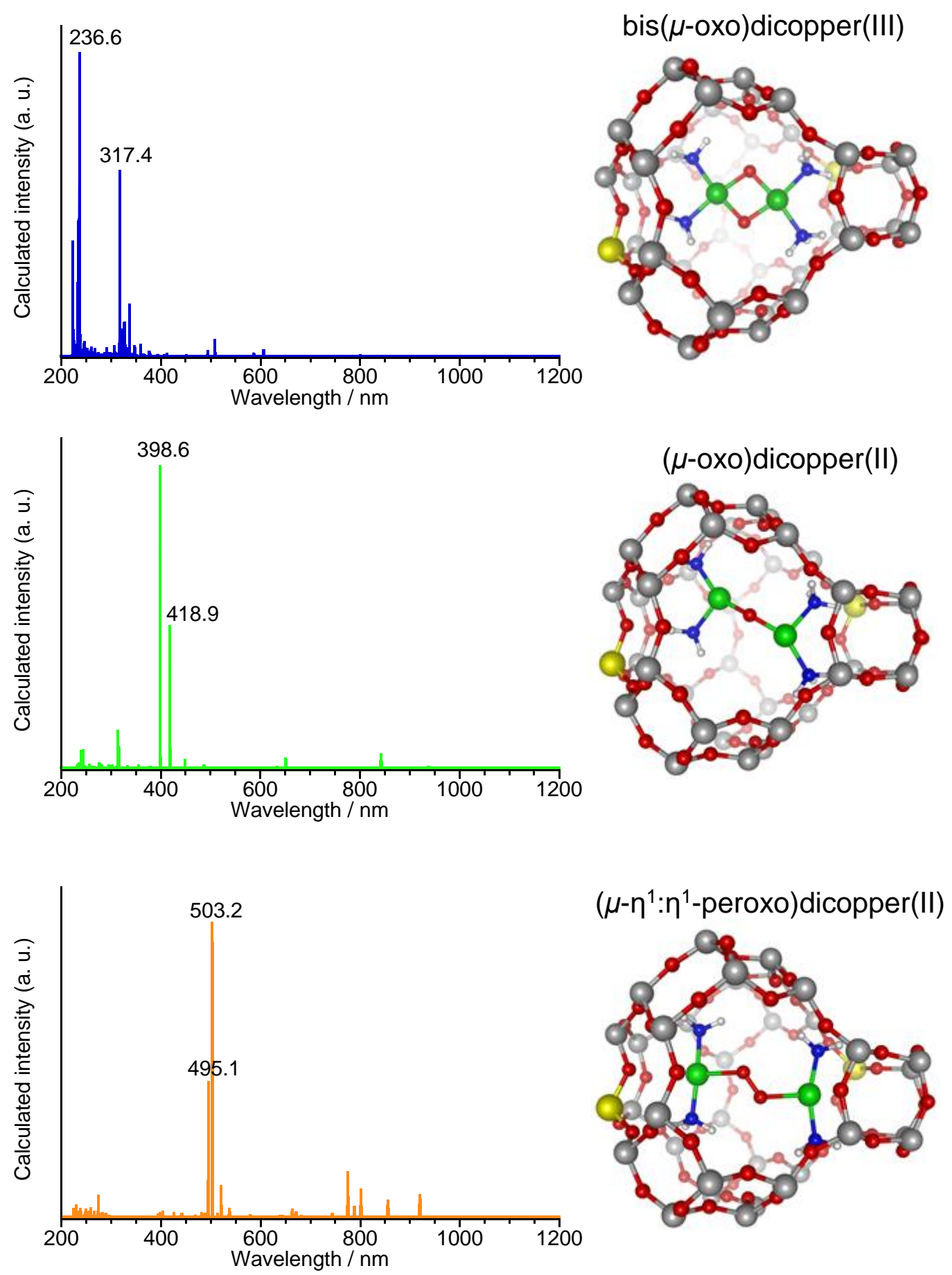

Figure S17. Computed UV-Vis-NIR spectra of the DFT cluster models of bis( $\mu$-oxo)dicopper(III), ( $\mu$ oxo)dicopper(II), $\left(\mu-\eta^{1}: \eta^{1}\right.$-peroxo)dicopper(II) species encapsulated within the AEI cage (FWHM=10 $\left.\mathrm{cm}^{-1}\right)$. Legend: green, $\mathrm{Cu}$; blue, $\mathrm{N}$; white, $\mathrm{H}$; yellow, $\mathrm{Al}$; gray, $\mathrm{Si}$; red, $\mathrm{O}$. 


\section{S4. Supporting References}

(1) Paolucci, C.; Khurana, I.; Parekh, A. A.; Li, S.; Shih, A. J.; Li, H.; Di Iorio, J. R.; Albarracin-Caballero, J. D.; Yezerets, A.; Miller, J. T. Dynamic Multinuclear Sites Formed by Mobilized Copper Ions in $\mathrm{NO}_{\mathrm{x}}$ Selective Catalytic Reduction. Science 2017, 357, 898-903.

(2) (a) Wulfers, M. J.; Teketel, S.; Ipek, B.; Lobo, R. F. Conversion of Methane to Methanol on CopperContaining Small-Pore Zeolites and Zeotypes. Chem. Commun. 2015, 51, 4447-4450; (b) Ipek, B.; Wulfers, M. J.; Kim, H.; Göltl, F.; Hermans, I.; Smith, J. P.; Booksh, K. S.; Brown, C. M.; Lobo, R. F. Formation of $\left[\mathrm{Cu}_{2} \mathrm{O}_{2}\right]^{2+}$ and $\left[\mathrm{Cu}_{2} \mathrm{O}\right]^{2+}$ toward C-H Bond Activation in Cu-SSZ-13 and Cu-SSZ-39. ACS Catal. 2017, 7, 4291-4303; (c) Li, H.; Paolucci, C.; Khurana, I.; Wilcox, L. N.; Goltl, F.; AlbarracinCaballero, J. D.; Shih, A. J.; Ribeiro, F. H.; Gounder, R.; Schneider, W. F. Consequences of ExchangeSite Heterogeneity and Dynamics on the UV-Visible Spectrum of Cu-Exchanged SSZ-13. Chem. Sci. 2019, 10, 2373-2384.

(3) Paolucci, C.; Parekh, A. A.; Khurana, I.; Di Iorio, J. R.; Li, H.; Albarracin Caballero, J. D.; Shih, A. J.; Anggara, T.; Delgass, W. N.; Miller, J. T. Catalysis in a Cage: Condition-Dependent Speciation and Dynamics of Exchanged Cu Cations in SSZ-13 Zeolites. J. Am. Chem. Soc. 2016, 138, 6028-6048.

(4) (a) Solomon, E. I.; Heppner, D. E.; Johnston, E. M.; Ginsbach, J. W.; Cirera, J.; Qayyum, M.; KieberEmmons, M. T.; Kjaergaard, C. H.; Hadt, R. G.; Tian, L. Copper Active Sites in Biology. Chem. Rev. 2014, 114, 3659-3853

(5) (a) Rode, M. F.; Werner, H.-J. Ab Initio Study of the $\mathrm{O}_{2}$ Binding in Dicopper Complexes. Theor. Chem. Acc. 2005, 114, 309-317; (b) Qayyum, M. F.; Sarangi, R.; Fujisawa, K.; Stack, T. D. P.; Karlin, K. D.; Hodgson, K. O.; Hedman, B.; Solomon, E. I. L-Edge X-ray Absorption Spectroscopy and DFT Calculations on $\mathrm{Cu}_{2} \mathrm{O}_{2}$ Species: Direct Electrophilic Aromatic Attack by Side-on Peroxo Bridged Dicopper(II) Complexes. J. Am. Chem. Soc. 2013, 135, 17417-17431; (c) Goswami, V.; Walli, A.; Förster, M.; Dechert, S.; Demeshko, S.; Holthausen, M.; Meyer, F. Acid/base Triggered Interconversion of $\mu-\eta^{2}: \eta^{2}$-Peroxido and Bis ( $\mu$-Oxido) Dicopper Intermediates Capped by Proton-Responsive Ligands. Chem. Sci. 2017, 8, 3031-3037.

(6) Midda, S.; Bera, N.; Bhattacharyya, I.; Das, A. Ab Initio and Density Functional Study of Spectroscopic Properties of $\mathrm{CuO}$ and CuS. J. Mol. Struc.: THEOCHEM 2006, 761, 17-20.

(7) Chen, L.; Janssens, T. V.; Grönbeck, H. A Comparative Test of Different Density Functionals for Calculations of $\mathrm{NH}_{3}$-SCR over Cu-Chabazite. Phys. Chem. Chem. Phys. 2019, 21, 10923-10930.

(8) (a) Oda, A.; Ohkubo, T.; Yumura, T.; Kobayashi, H.; Kuroda, Y. Identification of a Stable Zn ${ }^{\text {II }-O x y l ~}$ Species Produced in an MFI Zeolite and Its Reversible Reactivity with $\mathrm{O}_{2}$ at Room Temperature. Angew. Chem. Int. Ed. 2017, 56, 9715-9718; (b) Oda, A.; Ohkubo, T.; Yumura, T.; Kobayashi, H.; Kuroda, Y. Room-Temperature Activation of the C-H Bond in Methane over Terminal $\mathrm{Zn}{ }^{\mathrm{II}}-\mathrm{Oxyl}$ Species in an MFI Zeolite: A Combined Spectroscopic and Computational Study of the Reactive Frontier Molecular Orbitals and Their Origins. Inorg. Chem. 2019, 58, 327-338; (c) Oda, A.; Mamenari, Y.; Ohkubo, T.; Kuroda, Y. Spectroscopic Determination of the Site in MFI Zeolite where Cobalt (I) Performs Two-Electron Reduction of $\mathrm{O}_{2}$ at Room Temperature. J. Phys. Chem. C 2019, 123, 17842 17854; (d) Oda, A.; Nanjo, T.; Ohkubo, T.; Kuroda, Y. Experimental Description of Biomimetic Ni ${ }^{\text {II }}$ Superoxo $\delta$-Bond: Franck-Condon Analyses on Its Vibronically-Resolved Spectrum. J. Phys. Chem. C 2020, 124, 11544-11557.

(9) (a) Paolucci, C.; Verma, A. A.; Bates, S. A.; Kispersky, V. F.; Miller, J. T.; Gounder, R.; Delgass, W. N.; Ribeiro, F. H.; Schneider, W. F. Isolation of the Copper Redox Steps in the Standard Selective Catalytic Reduction on Cu-SSZ-13. Angew. Chem. Int. Ed. 2014, 53, 11828-11833; (b) Janssens, T. V.; Falsig, H.; Lundegaard, L. F.; Vennestrøm, P. N.; Rasmussen, S. B.; Moses, P. G.; Giordanino, F.; 
Borfecchia, E.; Lomachenko, K. A.; Lamberti, C. A Consistent Reaction Scheme for the Selective Catalytic Reduction of Nitrogen Oxides with Ammonia. ACS Catal. 2015, 5, 2832-2845; (c) MorenoGonzález, M.; Hueso, B.; Boronat, M.; Blasco, T.; Corma, A. Ammonia-Containing Species Formed in Cu-Chabazite as per In Situ EPR, Solid-State NMR, and DFT Calculations. J. Phys. Chem. Lett. 2015, 6, 1011-1017; (d) Lomachenko, K. A.; Borfecchia, E.; Negri, C.; Berlier, G.; Lamberti, C.; Beato, P.; Falsig, H.; Bordiga, S. The Cu-CHA DeNO ${ }_{x}$ Catalyst in Action: Temperature-Dependent $\mathrm{NH}_{3}$-Assisted Selective Catalytic Reduction Monitored by Operando XAS and XES. J. Am. Chem. Soc. 2016, 138, 12025-12028; (e) Gao, F.; Mei, D.; Wang, Y.; Szanyi, J. n.; Peden, C. H. Selective Catalytic Reduction over Cu/SSZ-13: Linking Homo-and Heterogeneous Catalysis. J. Am. Chem. Soc. 2017, 139, 49354942; (f) Zhang, R.; McEwen, J.-S. Local Environment Sensitivity of the Cu K-Edge XANES Features in Cu-SSZ-13: Analysis from First-Principles. J. Phys. Chem. Lett. 2018, 9, 3035-3042; (g) Fahami, A. R.; Günter, T.; Doronkin, D. E.; Casapu, M.; Zengel, D.; Vuong, T. H.; Simon, M.; Breher, F.; Kucherov, A. V.; Brückner, A.; Grunwaldt, J.-D. The Dynamic Nature of Cu Sites in Cu-SSZ-13 and the Origin of the Seagull $\mathrm{NO}_{\mathrm{x}}$ Conversion Profile during $\mathrm{NH}_{3}$-SCR. React. Chem. Eng. 2019, 4, 1000 1018

(10) (a) Groothaert, M. H.; Smeets, P. J.; Sels, B. F.; Jacobs, P. A.; Schoonheydt, R. A. Selective Oxidation of Methane by the Bis( $\mu$-Oxo)Dicopper Core Stabilized on ZSM-5 and Mordenite Zeolites. J. Am. Chem. Soc. 2005, 127, 1394-1395; (b) Woertink, J. S.; Smeets, P. J.; Groothaert, M. H.; Vance, M. A.; Sels, B. F.; Schoonheydt, R. A.; Solomon, E. I. A $\left[\mathrm{Cu}_{2} \mathrm{O}\right]^{2+}$ Core in $\mathrm{Cu}-\mathrm{ZSM}-5$, the Active Site in the Oxidation of Methane to Methanol. Proc. Natl. Acad. Sci. U. S. A. 2009, 106, 18908-18913.

(11) Elwell, C. E.; Gagnon, N. L.; Neisen, B. D.; Dhar, D.; Spaeth, A. D.; Yee, G. M.; Tolman, W. B. Copper-Oxygen Complexes Revisited: Structures, Spectroscopy, and Reactivity. Chem. Rev. 2017, $117,2059-2107$. 